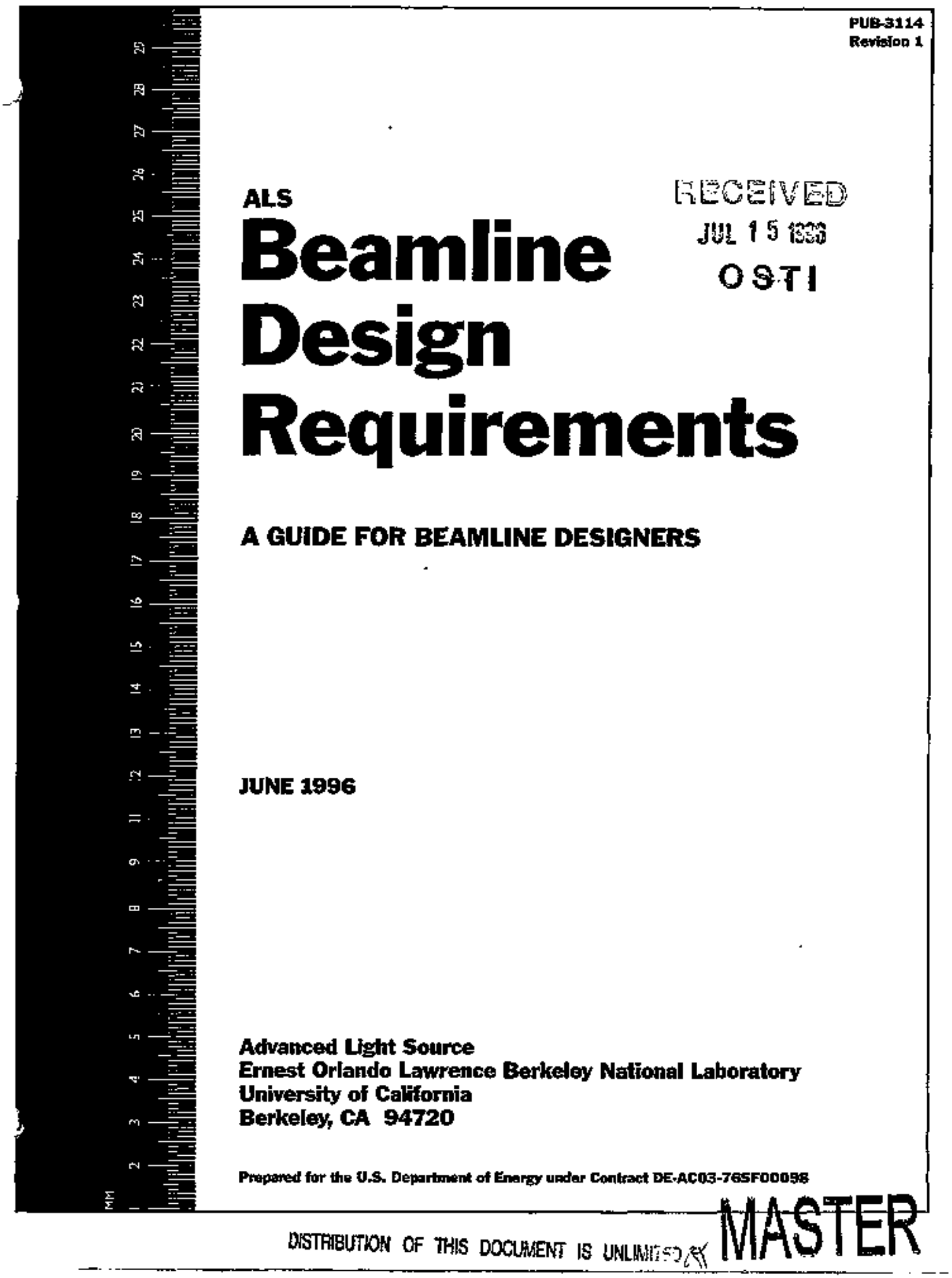


$+\ldots$

$1 \ldots$ 


\section{DISCLAMER}

Portions of this document may be illegible in electronic image products. Images are produced from the best available original document. 


\section{Als}

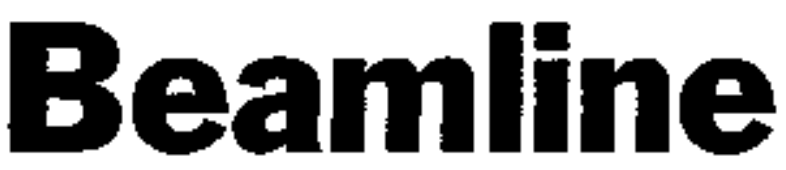
Design

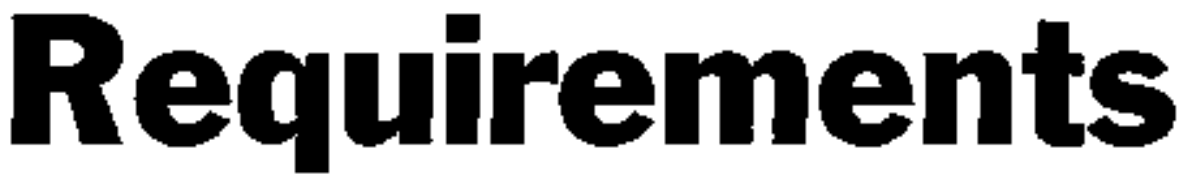

\section{A GUIDE FOR BEAMLINE DESIGNERS}

\section{JUNE 199- \\ Revision 1

\author{
DISCLAIMER
}

This report was prepanter as an accosat of thock sponsored by an agency of the Unined States

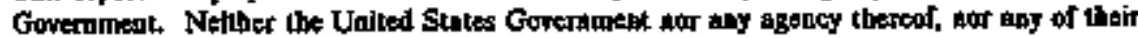

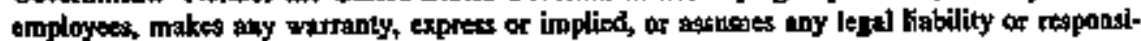
bility for the eccaracy, coldpteleness, or usefolness of any foformation, epparatos, product, of procese dlselosed, or represents that its use wouls not infinge prirgltly owned rights. Refer.

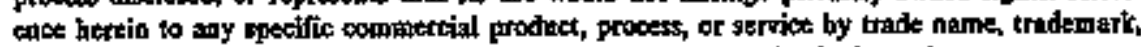
glanufacturer, or atherwise does not netessarly copstilute or inply its entorsement, recom. mendation, of Carotiog by the United States Gaverument or any ugency thereof. The viows and opinions of authors expresed berein do not necessarly state or reflect those of the Uniled Stales Gorernment or any agency therrof.

\section{Advanced Light Source}

Emest Orlando Lawrence Berkeley National Laboratory University of Calfomia Berkeley, CA 94720 


\section{DISCLAIMER}

This document was prepared as an aceount of work sponsored by the United States Government. While this document is believed to contain correct information, nelther the United Sates Government nor any agency thereof, nor the Regents of the Universicy of California, nor any of their employees, makes any warranty, express or implied, or assumes any legal responslbility for the acauracy, completeness, or useruhess of any information, apparatus, product, or process disclosed, or represents that its tse would not iniringe privately owned rights. Reference herein wo any speciftc cormmerctal product, processs, or service by its trade name, tradsmark, manufacturer, or otherwise, does not necessarily constituce or imply tits endorsement, recommendation, or faworing by the United \$tettes Government or any agency thereof, or The Regents of the University of Callfornia The views and opinions of authors expressed herein do not necessarily state or reflect those of the Unated States Government or any agency thereof, or The Regents of the University of Californita.

Enest Orlando Lawrence Berkeley National Laboratory is an equal opportunisy employer.

Dotumentation referred to th this doctment and additional copies of this mamul are avatiable from the ALS User Office, $510-486-7745$, Fax 510-496-4773.

The ALS values your suggestions. Flease send any comments tbout this publleation to Jane Cross at Jccross(6)|bl.gov. 


\section{Contents}

About This Manual

Beamline Definitions

Beamline Component Groups 1

Responsibility for Beamline Components 3

\section{Guidelines For Beamline Reviews}

General Information 5

Review Process 6

\section{Conceptual Design Review}

Goneral Information

\section{Beamline Design Review}

General Information 9

Documentation Package $\quad 9$

I. Radiation Shielding 10

2. Vacuum Components and Safety II

3. Electrical Safety 12

4. Utility Requirements 13

5. Fire Safety 14

6. Hazardous Materials 14 
7. Seismic Safety

8. Mechanical Safecy

9. Equipment Protection System

10. Survey and Alignment During Installation

II. Beamline/Endstation Layout

12. Hutches

13. Typical Experinent

\section{Construction Begins}

\section{Beamline Readiness Review}

\section{Appendices}

Appendix A

Gritelia For Beamline Bremsestrahung Shielding

Appendix $\mathbf{B}$

Adranced light Source Vacuen Pelicy and Vacumr Gubtelines for Beamines and Expentineut Endstations (LSB:-280)

Appendix C

Survey and Aligounent Information for ALS Users

Appendix

Bearnline Readiness fieview Malithrangi Prooedare (BL 08-07)

Appendix E

Cantacts for Adthicians bufonmation and Techinieal Questions

Appendix F

Cluecklist and Tresitine for Bualaing a Beamline

ALS User Atvisoties 


\section{About This Manual}

\section{PURpose}

Thits manual is written as a guide for researchers in designing beamlines and endstations acceptabte for use at the ALS. It concains guidelines and policies relaced to personnel safety and equipment and vaculdm protection, All equipment and procedures must ultimately satisfy the safety requirements set astde in the Lawrence Berkeley National Laboratory (LBNL) Health and Sofaty Manisal (PUB-3000) which is ayallable from the ALS User Office or on the World Wide Web from the LBNL Homepage (httpil) mww.lblgov).

\begin{tabular}{|c|c|}
\hline & AEBREVIATIOMS \\
\hline Bur & Beamling Design Review \\
\hline BRC & Beamline Reviaw Cornmittee \\
\hline BRR & Beamline Readiness Review \\
\hline CDR & Conceptuat Dosign Raview \\
\hline EH\&S & Enwronments Health, and Safecy \\
\hline EPS & Equipment Prorection System \\
\hline LCW & Low-Conductivity Water \\
\hline MOU & Memorandum of Underswnding \\
\hline PRT & Participating Research Team \\
\hline PSS & Personnel Safexy Shutxer \\
\hline RGA & Residual Gas Analyzer \\
\hline RSS & Radiation Safecy 5ystem \\
\hline UHV & Ultra-High Vacum \\
\hline
\end{tabular}




\section{Introduction}

\section{ABOUT THE ADVANCED LIGHT SOURCE}

The Advanced Lighe Souree (ALS) is a nadional user facility for scientific research and development located at the Lawronce Berkeley National Latoratory (LBNL) of the University of California. Its purpose is to generate beams of very bright light in the ultravioles and soft $x$-ray regions of the spectrum. Funded by the U.S. Departenent, of Energy, the ALS is open to researchers from industry, tuiver'sities, and government laboratories.

\section{RESEARCHERS AT THE ALS}

A researcher at the ALS can work as a member of a participating research tearm (PRT) or as at independent Investigator: PRTs (collaborative groups of people from industry, wiversizies, and or government laberateries) are responsitis for the design and construction of one or a combination of the followinge insertion device, beamline, endstations (expert. ment chambers). Independent investigatsors may bring experiment endstations to the ALS from other locations, or may use endstations provided by the AtS facility or by a PRT.

In eifter case, any teart or independent investigacor who brings a beamline or related equipment to the ALS must destgon the equipment such that it:

- Conforms with all applicable safety regulations

- Incorporater measures for the protection of the storage-ring vacutum and of costly beamline components. 


\section{Beamlịne Definitions}

\section{BEAMLINE COMPONENT GROUPS}

\section{Definition of a Beaminine}

Beamlines are photon deliwery systems that begin at the storage ring vaculum chamber and extend onto the experiment floor so include che experiment endstations. This definition of a beamline includes configurations with multiple branchlines and endstations.

A beamline might have multiple branchlines co accommodate different optical instrumentation. tach branchline might have multiple endstations to opti= mize timesharing of the beam. The simplest beardine configuration would have no branching and a single endstation.

\section{Beamline Configuration}

The figure below represents a generalized combination of conflgurations.

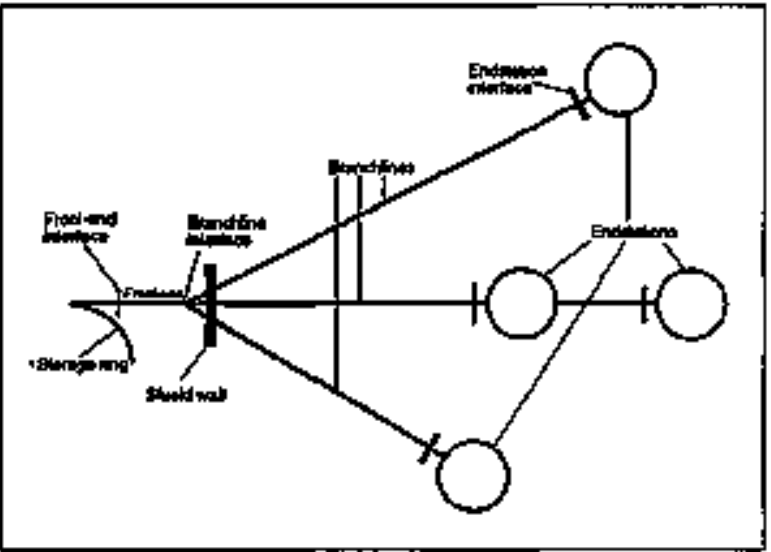

The three major beamline component groups are:

- Front end

- Branchlines

- Endstations
Even in the simplest configuration with no branching, the component group between the front end and the endstation will be called a branditine in this mamsal.

\section{Front End}

The front end begins at the storage ring vacuum chamber and ends at the branchline intorface, which is generally located innediately downscream (toward the experimenc) from the personnel safecy stutuer(s) at the shield wall. (In some cases the branchline incertace may occur further downstream or further upstream.)

Each beamline has one front end strared by all branchlines. The major components of a front end are

\begin{tabular}{|c|c|}
\hline COMPONEN'T & FUNCIIJN \\
\hline $\begin{array}{l}\text { Water-pooled } \\
\text { apertares }\end{array}$ & $\begin{array}{l}\text { Pass the entire or a partinl } \\
\text { width of the boam to } \\
\text { downstream components } \\
\text { whife protecting equipment } \\
\text { from thermal damage. }\end{array}$ \\
\hline Vacinam valves & $\begin{array}{l}\text { Permit isolation of the } \\
\text { beamline vacuum envtronment } \\
\text { from that of the storge ring }\end{array}$ \\
\hline $\begin{array}{l}\text { Water-cooled } \\
\text { photon shutter }\end{array}$ & $\begin{array}{l}\text { Closes to interrupt } \\
\text { transmission of the } \\
\text { synchrotron-radiation beam. }\end{array}$ \\
\hline $\begin{array}{l}\text { Personnel } \\
\text { safety } \\
\text { shutter }\end{array}$ & $\begin{array}{l}\text { Closes to provide } \\
\text { bremsstrahlung radlation } \\
\text { shitelding for the beamline. }\end{array}$ \\
\hline
\end{tabular}

Note: For bend-magnet bearnlines, space in the front end will be reserved for a possible mirtor chamber. 


\section{Branthrines}

The branchline component group begins at the branchline interface and ends at the endstation interface, which is immediately upstream from the first endscition component

Although the branchline section begins at the branchline interface, it need not begin branching at that point. On some beamlines with multiple branchlines, a region beginning at this interface and exterding downstrearn for a distance may contain instrumentation that is shared by all the branchlines. For example, a single mirror tank or aperture tark may be used to service all the branchlines.

The following component types are found in brancinlines:

\begin{tabular}{|c|c|}
\hline COMPONENT' & FUNCT'ION \\
\hline $\begin{array}{l}\text { Persomnel salétey } \\
\text { shutter }\end{array}$ & $\begin{array}{l}\text { Closes to provide } \\
\text { bremsstrahlung radtation } \\
\text { shielding for the branctiline. }\end{array}$ \\
\hline Optics & $\begin{array}{l}\text { Focus and filter the } \\
\text { synchrotron*radration bearn. } \\
\text { Foousing mirrors and } \\
\text { monochromators are } \\
\text { examples. }\end{array}$ \\
\hline Vacuenrm valves & $\begin{array}{l}\text { Isolate components for } \\
\text { installation, servicingt, and } \\
\text { equipment protection, tsolate } \\
\text { the branchline vacuum from } \\
\text { the attached endstation(s). }\end{array}$ \\
\hline Diagrostics & $\begin{array}{l}\text { Aligh and qualify optical } \\
\text { comporanc. Provide dam on } \\
\text { the properties of the beam. }\end{array}$ \\
\hline
\end{tabular}

\section{Endstations}

The endstation component group begins at the endstation triterface. It may consist of one or more experiment strtions. The components will vary depenting on the type of experiments being conducted.

Certain endstations, for example those on white-light beamlines, musc be surrounded by a hastch to protect persomel from radiation. 


\section{RESPONSIBILITY FOR BEABLINE COMPONENTS}

Policy

The responsibitity for the design, construction, and installation of the major beamline components will be specifically defined in a memorandum of underscanding (MOU) executed by the Als Scientifie Program Head and each PRT developing a beamlire. In general, responsibilicy is assigmed as follows:

\section{COMPONENT GROUP \\ RESP'ONSIB]LITY}

Front end

Branchlines

Endrations induding hurches
The ALS wil design all front-end components.

The ALS staff or a PRT may build a front end depending on the agreement reached in the MOU for that PRT. In etther case, construction of the front end will be based on designs provided by the ALS, with no modifications.

The ALS staff will Install the frome end for all beamlines.

The AL5 or PRT will design, bulld, and Install all branchline components, except as stated below or in the MOU.

- The ALS will design, build, and install all branchline ineerlodks and controls related to ratiation safety.

- The ALS will oversee sturvey and alignment of brandiline components during instalbation.

The PRT or an Independent investigazor will design, build, and install all endstation components, except as sated below or in the MOU.

- The ALS will design, build, and install all endstation interlods and controls related to radiaction safecy. 


\section{Guidelines For Beamline Reviews}

\section{GENERAL INFORMATION}

\section{Types of Beamiline Reviews}

The development of beamlines for ase at the ALS is monitored by the Beamltne Reviow Cormmittee (BRC). Every ALS beamline is subject to three reviews:

- Conceptual Design Review (CDR) at the sart of beamline development This is an informal revtew at which the concepttal design of the beamline, without the enginearing details, is outlined.

- Beamline Design Roview (BDR) before Installation of any beamline equjpment. This review examines the bearnline design, including the desigr of all equipment.

- Bearnline Readiness Review (BRR) following installation of the complete beamline and prior to initial operation. The BRR Includes testing to ensure chat the beamline can operate safely. The ALS will overses this testing. Final authorkation for routine beamline operation is given by the ALS Director or desigree.

These reviews may be repeated if modifications are made that wamant review or if signaticant issues require furcher chrification.

\section{Purpose of Beamline Reriess}

Beamlines are revtewed to ensure that their compo. renes and equipment satisfy all ALS, LBNL and DOE requirsments for safa operztion. The documencation developed for the reviews and during the review processes is kept on file and is accesslble for reference whenever information about the beamline is required.

\author{
Who Gopducts Reviews? \\ Conceperal Design Reviews, Beamline Design \\ Reriews, and Beamline Readiness Reviows are \\ conducted by the ALS Beamline Review Committee. \\ This committee consists of the ALS Environment, \\ Healch, and Safety (EHES) Program Manatser, the ALS \\ Mechanical Group Leader; members of the ALS staff \\ who have expertise in beamline dosign, construction, \\ and operation; and members of LBNL's EH\&S Divi- \\ sion.
}

\section{How Long Doos the Process Take?}

Typically, development of a beamline from concept to implementation takes many months. A Conceptual Design Review (CDR) should be scherduted as soon as the beamline concept is defined. The Bearnline Design Review (BDR) should take place while the beamline is still in the designt stage and before ordering components, so that no hardware will bave to be alcered. It is reconnmended that the. BDR be conducted 6 months (absohtse minimum is 3 months) before the tensative dats of the first operation of the beamline. The documentation package for the BDR, described in the Beamline Design Revlew section of this document, must be receired at least 2 webks before the BDR is schoduled. The Beamline Readiness Review (BRR) akes place a few days prior to first operation. The Bearnline Review Committee intends that the review process should not cause any deby to the design and implementation of a new beamint.

\section{Sclteduling a Beastine Reriow}

To schedule a review, please contact the head of the Beamline Revlew Committee. This position rotates annualiy, for the name of the current chalr contact the ALS Administrator:

Elrzabech Saucler

ALS Adminlstrator

Advanced Light Source, MS 80.101

Lawrence Berkeley National Laboratory

Berkeley, CA 94720

(510) 486.6166

(5I0) $486.4960[\mathrm{Fax}]$ 


\section{REVIEW PROCESS}

The beamline review process is outtined in the following flowchart

Beamline designersubmits

conseptual design to Beamine

Review Conntiles (BAC).

Comnut conducts intormel

Corceptual Des[gn Revlew ard

communice

brarillan des[grier.

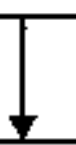

Beanuline designer submito docur mentation as requhed for a Beam line Desigl Aetieu (BOF) to BAC

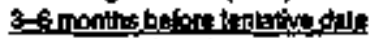

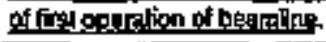

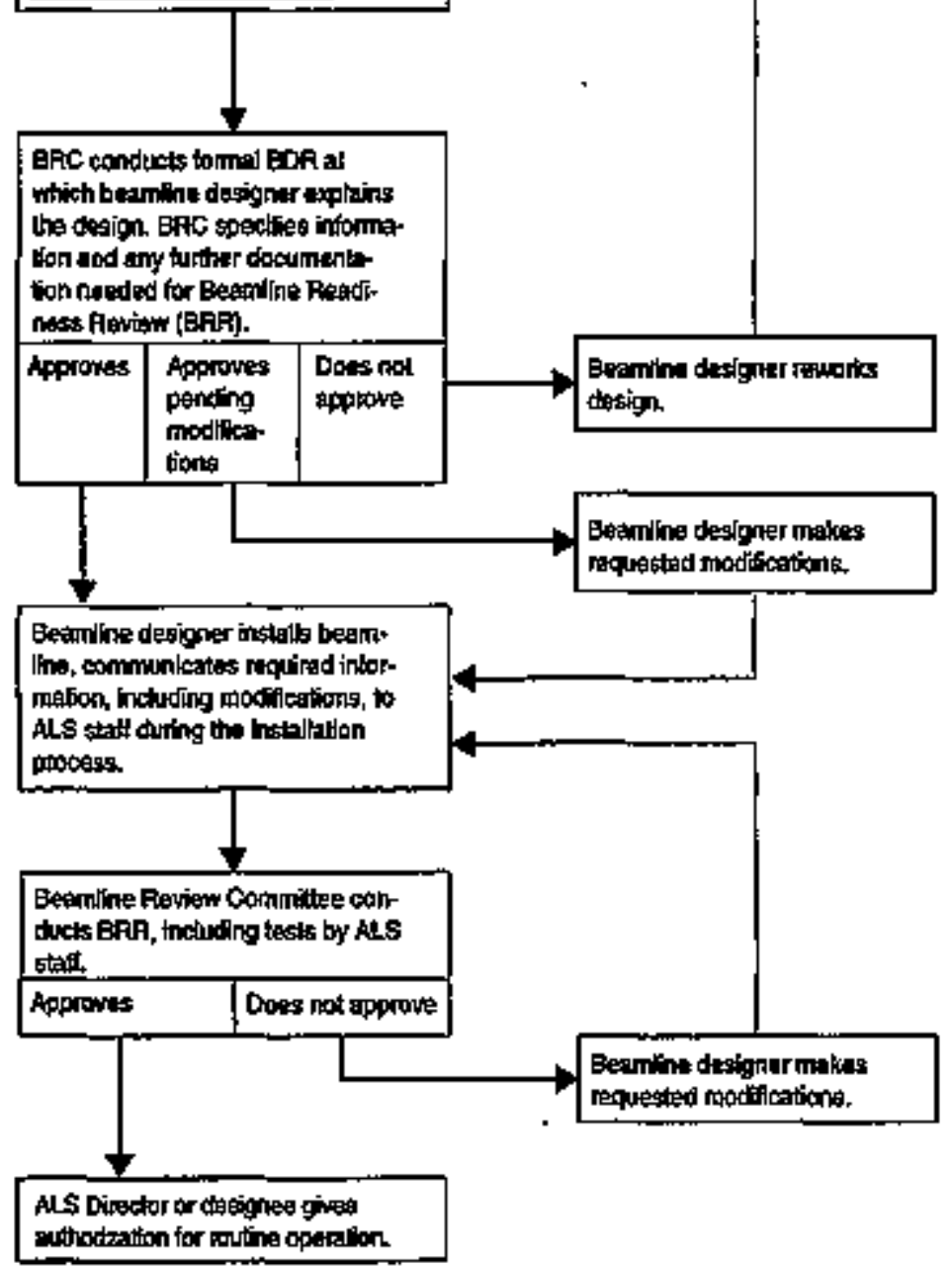




\section{Conceptual Design Review}

\section{GENERAL INFORMATION}

\section{Definition and Purpose}

The Conceptual Design Review (CDR) is an informal review conducted by the Beamline Review Committee at the earliest possible stage of bearnline development It is incended $w$ :

- Allow the beamline designer to communiate the conceptual cutline of the proposed beamline, minus the engineering details, to ALS staff.

- Give ALS staff the opportunity to examine the preliminary designs and offer suggescions on how best to utilize allocated space and materials in order co fully exploit the spectial properties of the Als synchrotron radiztion source.

- Esablish lines of corramanication between the beamline designer and ALS staff to factlitate and coordinate subsexuent steps it the begmline development process.

Whed is a Contequtud Desien Beriew Conducted? A Conceptual Design Review (CDR) should be scheduled as soon as the bearrine concept is defined. 


\section{Beamline Design Review}

\section{GENERAL INFORMATION}

\section{Doffintion and Purpose}

At the Beamline Design Review (BDR), the beamline designer presents the detailed design to the Beamine Review Committee which examines the design of all equipment before inseallation begins to ensure dat the beamline widl:

- Operate safely in accordance with all applicable regutations on radiation, sectrical safety, fire safety, hazardous materials, and seismic safect.

- Maintain the quality of the vacuum ton the storage ring and protast costly components of the beamline itseff.

- Be configured to allow access or egress toffirom surrounding areas, conform with space allocation, and not interfere with the safe operation of the ALS.

A Beamline Design Review is distinct from an Expertmenc Safety Review. The former evaluates "perma. nenc beamline component," whereas the tarcer evaluates the equipment and materials brought to the ALS to conduct specific experiments. Only one BDR per beamline will be required unless substantial changes are made to the beamline design. In contrast. an experiment safecy review will be conducted for each experiment performed on a beamline.

When is a Beamiline Design Rerfew Condacted? The Beamlthe Design Review fot a beamline will be conducted before any equipment is inscalled on the ALS floor It is recommended that the BDR be conse 6 months_(absoluse minimum is. 3 months) before the centarlye date of flect opperation of the beamline (and before funds are commitred to fabricare expenstve components). Thus, the beamline developers should schedule the BDR through the Beamline Revlew Commlttee well before any beamline equipment is due to be installed on the ALS floor. A beamline is also subject to a Beamline Design Review after its installation if substantial modifications have bean made.

\section{DOCUMENTATION PACKAGE}

\section{Conterits of Package}

Each itam on the following list (if applicable) must be prepared by the beamline destgner and 11 copies of the complete documencation package muse be submitted to the Beamline Review Committee at least two weeks before the BDR is scheduled. Ses Appendix E for persons to contact for specific iterns on the list.

I. Description of radiation shielding

2. Description of racuum components and safecy

3. Description of electrical safety measures

4. Descatption of tuilizy requitements

5. Description of fire safety measures

6. Descripcion of safecy measures with respect to hazardous materials

7. Description of seismic safety measuress

8. Description of mexhanical safecy measures

9. Desciption of equipment protection system

10. Description of survey and alizament fiducials on beamline comporents during instalation

II. Drawings of beamline/endstation byout

12 Description of hutches (If used)

13. Description of a typlcal experiment

\section{For More Information}

The following sections give thformation on the details to be incluted in eadi documentation category together with additional information to assist the beameline designer. A checklist and a suggested timeline for completion of bearline documentation and conscruction are given in Appendix $F$. A sample BDR document padage is avallable from the ALS User Office, for contact Informadion see Appendix $E$. ALS User Adylsories containling addtelonal Information about design and installation requirements of beamline equipment are In Appendix G. 


\section{RADIATION SHIIELDING}

\section{Documentation}

The documentation for a Beamline Design Review musc describe the radiation shielding that will be used on the beamitine components. Plesse include the following information:

- Anamorphically sciled ray-trace drawings widh dirnensions, showing the imporeane lises-of-sight through the opening in the storage ring shield walt, and the shiplding ageinst bremsstrahlung radiation. These dratrings will be used to verify the adequacy of che shielding and to check the location of the shielding once the beamline has been instalied. All major components and shielding must be labeled essing the method shown below.

- Anamorghically scaled drawings of exclusion zones and description of equipment for preventing personnel entry into line-of-sight bremsstrahlung radiation when the personnel safezy shurter is open.

The ray-trace drawings are prepared by the beainline designer with assistance from the ALS Metranical Engineering staff as required. It is strongly recornmended that beamline buitders start commsnicating the information related to strelding as soon as the preliminary design for the beamline is completed as it may rake a few imeractons before the shieiding design is ninalized.

\section{Labets}

The kbels for the bremsstrahlung shisiding and exclusion zones should follow the format described below.

$$
\begin{aligned}
& \text { B(number of branchline)_BSxx } \\
& \text { B(number of branchilne)_EXxx }
\end{aligned}
$$

Where $x x$ indicates the number of the shield or exclusion zone. The bremsstrahlung shields and exclusion zones should be numbered sequentlally starting from the storage ring.

Examples: B7.0.1_BSOI specifies the first bremsstrahlung shielo on branchline I of the undulator beamline in storage ring sector 7 .
B93.1_EZ08 specifies the eighth exclusion zone on branchline I of the bend-magnet beamline coming off the fourth port in stomge ring sector 9.

There identifiers should be written on permanent labeds and affixed to the most accessible side of the shiektling or exclusion zone to provide quick and easy identification. The lettering should be at least $2 \mathrm{~cm}$ $(B \mathrm{in})$ high to make the labets easy to read firom a distance.

\section{Guidelines}

a. Personnel safety shutoers (PSS) are installed by the ALS as part of the front end of almost every beamline. When the PSS are closed, there is sufficienc overlap of shiekting elements inside the storage ring shield wall to prevent any radiacion from emerging anto the experiment floor during mortmal operation. When the PSS are opened to pernnit symchrotron rabitation into the bearnline, there is also a component of high energy bremsstrahiung which emerges along lines-of-sight from the storage ring. Thls radiation must be collimated by lead shields and contained inside the beamplpe or exchuston zones until the synchrotron Fight can be deflected by a mirror so that the remaining bremisstrahtung can be intercepted and absorbed.

b. Personnel safety shutters must be fail-sefe, with redurdant electrical controls interlocked to position-indlcator switches in order to afford maximum safety for personnel. Beamkine designers are required to use an ALS design for personnel safety shutters. The ALS will also tesign, build, and install all personnel safety Interlocks.

c. Some beamlines require a hutch because bremsstrahlung ractation is present at the end. station.

d. Routine user access noty be requlred to the Incerlor of hurches and to other resions in which radlation is present during beamline operation. These situations cal for additional radiation safecy interlock systems and possibly additional personnel safiey shutters to ensure that the PSS ars closed during controlled access. 


\section{For Hore Information}

For Information on preparing anamorphic dratings and additional detwils on requirements for bremsstrahlung shielfing, see Appendk $A$. For convet information for assistance in designing raciation shielding, see Appendix E, Radiation safety requirements and estimates of synchrotron radiation can be found in Als Symctirotion Radiation Shjelding (LBL-379DI), avaibble from the ALS User Office; see Appenditx $E$ for contact inforriation.

\section{VACUUM COMPONENTS AND SAFETY}

\section{Docmenentation}

The dacumentation for a Beamline Design Reviow must inckude a description of the vacuum components of the bearnline and endstation(s), including the following detalls:

- Schematic diagram of vacuum chambers, valves, and connections

- Description of materials used in UTHV systems

- Description of ion gauges

- Types of pump(s), locations, speeds, and interlodk systems

- Description of vacuutm isplation valies and interlock systerns

- Fast-valve sensor locations

- Design of thin windows

- Design of gas cells

- Designt of tooling systerns.

\section{Gnidellines}

Preventing contangination of beamlines and the storage ring is an inportatis coneern at the ALS. For example, as little as 0.1 cc of pump oil could perma. nently rutn the entire storage ring vactutsn chamber. Only a singte fast valve procects the storage ring from sutedden bearnline vacuum actidents. Beamline designers and AlS users muss recognize that a high level of vacuum safety is neexled for all equipment tomected to the AlS vactum chamber.

\section{For thore tromation}

See Appendix B, AtS Voctum Palicy and Vocentum Guidelines for Beamlines and Experiment Endstotions (LSBL2a0), for information covering all aspects of vatum fety in beamline design, and Appendix G,ALS User 
Advisories for detailed guidelines on vacuum policy, interlock requirements for turbo pumps, and vacuum safety when toxic or corrosive gases are in use.

These appendices should be read before the design of the beamline begins.

\section{ELECTRICAL SAFETY}

\section{Documeatation}

The documentation for a Bearnline Design Review must list alt electrical equipment chac will be part of the branchline(s) and endstation(s) and give the function and specificatlons for each item.

\begin{tabular}{|c|c|}
\hline \multicolumn{2}{|c|}{ Example } \\
\hline Function & Specification \\
\hline $\begin{array}{l}\text { lon pump power } \\
\text { supply }\end{array}$ & $\begin{array}{l}\text { Ouputyolrage } \\
5 \mathrm{kVDC}\end{array}$ \\
\hline $\begin{array}{l}\text { Sublimation pump } \\
\text { power }\end{array}$ & $\begin{array}{l}\text { Ourpur culrent } \\
60 \text { amps } \\
\text { Output volinges } \\
10 \text { VDC }\end{array}$ \\
\hline
\end{tabular}

\section{Gutidellaes}

All electribal equipment usat in conjunction with beamines must satisfy the electrical safocy requirements established in the LBNL Heaich and Soffety Manual (FUB-3000), Chapter 8. "Electrical Safety;" and Chapter 21, "Lockout Tagout," and In the current edition of Notiand Electricel Code, ANSINNFA 70. Following are a fow importent guidelimes from these sourses.

a. Wirting installed in open cable trays mast be labeled as suitable for cable trays.

b. Exposed terminals $\leq 50$ volts must be isolated by endosures, covers, screw-on panels, or by interlacked deors. Appropriate warning signs must be afixed to all daors and covers.

c Energy-storage devices (such as capacitors) capable of storing more than 5 joules of entargy must be equipped with automatic discharge devices such as shorting relays or biteder resistors that discharge to safil voltage ( $\leqslant 50$ volv) when the equipment is do-anergized or when the capacitor enclosure is optened, The energy must be discharged within a time no greater than the time needed for personnel to gain access to the vologe terminals. In no case must this time be longer than 5 minutes. 
d. To efliminate the danger of lethal voltages appearing between the vacuurn chanber and elecrronic ground when tonization gauges and ion pumps arts in operation, the vacuum chamber must have a common electrical ground with the gauge control or ion pump power supply.

e. Beamline components must be property grolanded, especially during bakeout All heaters used for bakeout must be protected by a grouns fault circuit Interruperer (GFCl). The ALS routinely installs GFCI at tonvenient locations alang the beamtine.

f. Split heater-tape connectors must be permanently bonded together to form one assembly or replaced with a single, unified connector; split connectors are not allowed.

g. Dise to the high voltage supplied co ion pesmps, certain cables and connectors may require an ALS retroflc for example, where exposed atiles could be damagsd on vacusm systems usting Perkin.Einer equipment exclusively, the high-voltage cable (RG142 coax) must be contained along with a \#12 ground wire in a $5 / 6^{\prime \prime}(21 \mathrm{~mm}$ ) flexible armor condult A specially designed safocy cable clamp (ALS \#23W1734) is installed on the tan pump end of the high-volage able and a condult clamp is installed on the centroller end. The ground wire is then terminated to both the lon ptump and the controller, Similar proteceive measures may be regatired for othor martufacturers' equipment contact Als Eloctrical Engineering stoff for more information.

When cexpinating a

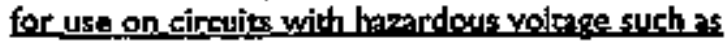
bon-pump-ables, ars should be aken to terminite thesupply-and last if the load (ptmp) end is being modified or ra-terminaeed, the supply-end connector should be isolated in 2 lock-out device.

For Wore Infarmation

Additional information on electrical safety at the ALS can be found in ALS User Advisories in Appendix G, and in the ALS Sofety Hondbook (PUB-745), ayailable from the ALS User Ofilce; see Appendix E for contact information.

\section{UTILITY REQUIREMENTS}

\section{Documentalion}

The documentation for a Beamline Dasign Review must provide a list of all utilly requirements for the beamline including:

- Electrical power requirements

- Distribution layout

- Compressed air or nituogon distribution requíre. ments

- Low-conductivity water (LCW) requirements including flow, temperature and presture

- Exhaust manjfold layouts

\section{Cautdetines}

Utilities and services available at the Als inchude:

- Eleetrical power: 480 VAC, 208 VAC, 120 VAC, single and 3 phase, $60 \mathrm{~Hz}$

- Low-conductitity (detonized) water

- Compressed air or nitrogen

- Exhauss manifold system

- Machine stopos, including plazing and wolding

- UHV facilities, induding vaetum brazing

- Electrical and electronic fabrication shops.

Beamline utilicy racks should be numbered as described in Ais Beamline Rack Numberings Stheme (LSEE-107A), available from the ALS User Offices see Appendix $E$ for contact information. 


\section{FIRE SAFETY}

\section{Docendentation}

The documentation for a Beamine Design Review musc describe the following:

- Any flammable chemizals and solvents that may be used in the operation or mainterance of the beamline, apart from those used in individual experinents.

- Electrical equipment containing flammable lluids or to be used routinely in assoctation with flanmable fluids.

- The layout of escape ajsles around expertments and beamlines.

\section{Gridelines}

Please do not plan on storing flammable or otherwise hazardous chemlcals in cabiness in the trmediace beamline area, even in small amounts, Such macerials may be used in an experimench however they metst be stored in designated locations provided by the ALS. The number of cabints allowed for storing such materials on the Als floor is limie?d by fire regudations.

\section{HAZARDOUS MATERIALS}

\section{Dacumentation}

The documentation for a Bearnline Design Review must provide the following information concerning hacerdous materials.

- A list of any hazardous materials that will be used in the structure, regular oparation, or maintenance of the bearitine, apart from those used for particular experinents. Flease describe how each materlal will be used.

- A list of any hazardous materials that may be pumped through the system.

- A description of any beryllium windows used.

\section{Guideines}

a. A hazardous matertal is one that can potentially pose a healch hazard (e.g, radioactiva materiats, carcinogens, toxkc agens, ir ricans, corrosives, or hazardous biological substances) or a plyrsical hazard (e.g, flammables, cryogenics).

b. Haxardous matsrials art not allowed in the AL5 experinent area without prior approval. If hazardoes materials are approved for use with your beamline, please do not plan on storing them in the Immediate beamline area, even in small amounts. They must be stored in designated bcations provided by the ALS.

c. Cleaning procedures requiring the excensive use of solvents must be conducted in the baboratory prowided for this purpose and not in the experiment area, it is therefore retommended that squipmene be designed to be disassembled for cleaning.

d. Hazardous pump exhatst must be vented through the exhaust system provided by the Al.S.

e. All besmlines must satisfy the ehemital safery requirements in the LBNL Health and Safey Manuai (PUE-3000), Chapters 5 and 30 , and is the LBNL Chemical Higtiene and Sofety Plon (PUB-5341). The latter publitation contains requlations for spetific chemieaks. 


\section{SEISMIC SAFETY}

\section{Documeutation}

The doetumentation for a Beamline Destgn Review must deseribe the measures taken for seismic safety. Please include the following information:

- A description of the beamline and endstation components and equipment from the seandpoint of seismic strbility. Include an estimate of the mass and the height of center of gravity for each component.

- A descripzion of the containment to prevent dispersion of chemical reagents radioactive, infectious, pyrophoric, ilammable, or toxic materials.

\section{Gutdelines}

All expertiment equipment installed at the ALS must be in compliance with the seismic-safecy eriteria specifted in the LBNL Heaith and Sofety Manual (PUB-3000), Chapter 23. The thent of these criteria is to ensutre that the equipment is destgned to resist. without collapse, earthquakes of magnitude 7.0 Richter on the Hayward falt and those of magnitucte Q.3 Richter on the 5 an Andreas fatth. For corrvenience these eriteria are summarized here; however, this summary is not intended to be comprehensive.
For exulipment which, due to size or unlque strucoure, requires specialized selsmic stabilization, additional criteria may be required. Any such crtterh will be reviewed by ALS Engineering staff.

General Criteria. Objects not easily restralped by one person must be prevented from kaceral movement and from overturning whtheut reliance on friction when the object is subjected to a $0,7 \mathrm{~g}$ hateral acceleration through its eenter of gravity. It is recommended that equipment be designeo to withseand a lateral acesierztion of $1.0 \mathrm{~g}$ or greater.

Dynomic Analysis. For heary equipment or other objects mounted on support stands, the dynamic load during an earthquake may, because of resonance, greadly exceed the maximum ground acceleration. Support strutetures should be designed with enough rigidity to achieve natural frequencies above $20 \mathrm{~Hz}$. For structure with natural frequencies below $20 \mathrm{~Hz}_{1}$ the effect of ths resonance can be significant Structures in this category may require a dynamic struc: tural anabysis to be done by the ALS Engtheering Group.

\section{For Hore Information}

Refer to ALS User Advisories I and 4 in Appendix G for additional information regarding seismic ssfety requirements for user equipment. 


\section{MECHANICAL SAFETY}

\section{Docmmentation}

The documencation for a Beamline Design Review must describe any potentially hazardous mechanical components so as to document the associated safety measures. Ecamples of such potential hazards are.

- Lifting fxxures and rigging

- Vacuum vlewports which are custom designed or have apertures that are $>15 \mathrm{~cm}$ ( $6 \mathrm{in}$.)

- Moving components with potential to injure personnel

- Pressure vessels

- Enclosed spaces

- Ladders and steps

- Phtforms and gantries.

\section{EQUIPMENT PROTECTION SYSTEM}

\section{Dombmentation}

For a Beamline Design Review, the documentation of the equipment protection system for a branchline or endstation should include:

- An instrumentation diagram describing all major equipment protection components

- A complete description of all equipment-protection interlocks

- A description of the interface between the beamline equipment protection system; and the ALS-designed parts of the beamline control system and the ALSdesigned radiation safety system (RSS).

\section{Goidelines}

The purpose of an equipment protection system for a beamline is to prevent dantage wo componenes that would be vary expensive to replace and to protect the storage-ring vacustm.

a. Beamline designars are expected to design, build, and install equipment protection systems (ineluding incorlocks) to work on all braneflings. Thesse systems mtrst automatically mospond to equipmentprotection faules, which generally fal into two enegories: vactum and thermal, Vacuum interlocks must be provided to protect the integrity of the bearnline vacuum. Therrmal interlodes and water. flow interlocks must be providiod to protect cooled components.

b. The equipment protection system should perform three major functions:

- Permit operation of the beamline only if protection devices are operating correctly. If the equitoment protection devices fait, a control fautx is produced and the equipment protection $5 y$ stem takes approprlate action in response to the faulc. For example, if an ion-gauge controller detects a leak in the vacuum system, valves must dose to isolate the leak and the photon shutter must close to protecc the valve from beam heating. 
- Partition selected areas with beam stops so that soturces may operate while some beamlines/ branchilines are off-Jine for maintenanse or exper:tinent setup.

- Mediate signals between the branchline's equipmenc protaction system and the radiation protection control system.

c. The equipment protection syscems for beamlines designed by the ALS use programmable logic controllers and interface with the operator station and instrement-control sysem through a dedicated RS485 network. Beamline designers may wish to take the same approach. d. The use of manual racuum valves atong the beam path is strongly discouraged because they fintertiere wich effective attomated EPS responser.

e. Equipment protection systems that require accion in the from end (for example, those that require the ghoton shutter to close) must communicate with the ALS front-end control system. This cormmunication an be Implemented by the followIng signals which interface the equidment protection system (EPS) of the frone end (FE-EPS) with that of a given branchline (BR-EPS):
\$IGNAL

BRFE_VAC_PERMIT

INPUTS FROM

BR-EPS

To

HE-EPS
BRFE_NONVAC_PERMIT

\section{FUNCTION}

Inditates safe vaeutum conditions in the tranchline. When FALSE, the frontend EPS will close the branciline isolation valve $B R$. WRI, the first vacuum isoktion valve for the branchline.

Indiates safe non-vaouum conditions in the branchline. When FALSE, the front-end EPS will dose the branchiline photon shucter BR_PSI.

\section{OUTPUTs} To BR-EPs From FE-EPS
RRFE_VAC_OPEN

BRFE_VAC_CLOSED

BRFE_NONYAC_OPEN

BRFE_NONVAC_CLOSED

BRFE_PASS_BEAM
Indicates that branchline isolation valve BR_WRI is open.

Indicates that branchline isolation valive BR_WRI is closed. Indicares thac branciline photon stutzter BR_PSI is opent. Indiates that branchline photon shutter BR_PSI is closed.

Indicases that beam may pass through fronc end to branchline. 


\section{SURVEY AND ALIGNMENT DURINE INSTALATION}

\section{Opclimequation}

If ALS survey and alignenent is required, the documentation for a Beamlins Destign Roview should show which comporents will be fiducialized and the locations of the frductals. If fiducials will not be used, pleass describs the plans for alignment.

\section{Guidedines}

a In general, the components of a branchline that require preciston alignment (e.g, mirrors, slits, masks, and gratings) are inside vacuum chambers and not accessible from ouside for survey and alignment Consequently, these companents require "fiducialization" during the assembly of the branchline, that is, the pasizion of important internal feacures musc be measured relative to accessible fiductal references outside the vacuum chamber. These fiducials are then used for surver and alignment at inscallation. For a given compo. thent, fiducialization geverates a set of Carterian coordinater (U, $V$, and $W$ ) for each fiducial in a local coordinate system. The location of the tiducial origin (t.e., the mirror center, etc.), and a direction must be specified in the beamline coordinate system. b. Three fiducials are required for placing a component in space with 6 degrees of freedom, but four fiducials aro highly desirable for redundancy, allowing a chesk on the survey and altignment. Fiducials are usuatly a $1 / 4$ inch precision hole which accepts a "tooling ball" for mechranical contact and measurtment. The fiducials should be located with as large separacion from each other as possible and a dear vertical path above for accessibility.

c. The optical argets are constructed such that their optial center exacty coincides with the center of the tooling ball when interctanged the the same hole. This center point is the fiducial point with the coordinates $U, V$, and $W$.

d. Weld-on fiductai poscs that accept the optical trorgets and the tooling balls are described in LBNL Mechanioal Engineering Drawing 20 Q 5363. These fiducial posts have been used successfutly throughout the ALS and are recommended.

\section{For More Information}

See Appendix C for additional decails on the ALS systeri for survey and alighrment. 


\section{BEAMLINEJENDSTATION LAYOUT}

\section{Doesumentation}

The documentation for a Beamline Design Review shotld include drawings of the overall beamline layouc Drawings should show lowations of:

- Storage ring

- Front end

- Beamline shielding, showing labeling

- Exclusion zones, showing labeling

- Vacuum valves, with names as used for the EPS

- Ion gauges, with marnes as used for the EPS

- Fast valve sensors, with names as used for the EPS

- RGA locations, with labeling

- Water flow switches and other equipment protection dsvices
- Hutches (If appropriax)

- Endistations

- Support equipment (e.g., racks, tables, etc.)

- Walkways around beamline and endsation(s), and an escape atsle.

\section{Guidelines}

a. All major components and shiefding must be labeled. Shielding and exclusion zone labels should be labelled according to the format described both in the Radiation Shlelding section of this document, and in Appendix A. EPS components should be babeled with EPS system mnernonics.

b. In addition to the detailed bearnline drawings, a plan drawing of the entirs beamline, induding control radks and space requirements, must be provided to the ALS in electronic form. ALS staff will apply the "footprint" of the new beamline to the ALS master floor layout drawing. 


\section{HUTCHES}

\section{Doctumentation}

The doctumenzation for a Beamline Design Review should include a deseription of the hutch design, if applicable, ineluding the following details:

- Materials ursed (specify thickness)

- Penetration lengths

- Window materials

- Door security

- Fire safecy measures

- Venzilation system

- Structural stability.

\section{G:ldelines}

A hutch is regalired whenever routine tecess is to be avaibable to an area in which radiation is present during beanline operation, and the method of access does not predude a radiation hazard. Ac the ALS this sianation arises when access is required to an area which receives bremsstrahlung radiation on a line-of-sight through the opening in the storage ring shleld wall or when high energy synchrecron radiation passes into the atmosphere through a this window. Hutches may admite personnel, or smaller eqnelosurats may be netessary which admit only hends and arms. In either case, the ALS will design and build a special rediation safety system to ensure sato access. Access to a vactum enclosure in a low tonergy beamline in a location where there is no bremsstrahlung and where the synehrotron light cannot penetrate the vacuntm valves is not a hazard in this category.

Interlocks to ensure radiation safety musc be developed such that their circuits and components are fillsofe to the greacest extent practicable. That is, in case of a component or power failure in the interlock system, te musc react to render the area sofe. The incerlock system must also be redundant that is, two independens secs of components and circults must be developed to ensure sofaty in the evene of a failure of one circuit Beteruse these systems art so cricical to personnel safety, the ALS will design, build, install, and tese the radiation-safery interlocks for hutehes.

\section{For blore Informition}

Additional information regarding escimates of ALS synehrotron radiation and radiation safecy requirements an be found in ALS Symetrotron Rodiation Shielding, (LBL-37901), avatable from the ALS User Oftice; see Appendix E for contact information. 


\section{TYPICAL EXPERIMENT}

\section{Dacementation}

Brielly describe a typical experiment condected on the beamline. Describe the following as appropitate.

- Major piezes of equipment particular to the experiment and how they are used

- Duration of the experiinent

- Pressures and temperacures at yarious locatons in the endatation
- Hazardous equipment and protection

- Hazardous materials used or gensarted.

Note: The BOR dons not review the planned experiments. That review is requested via an AlS Experiment Form available from the ALS User Offiet. This form requests spedifle Information above potentally hazardous maxerials to be used or generated and abous potentally hazardous equipment to be used. A form must be completed for each experiment. 


\section{Construction Begins}

\section{GENERAL INFORMATION}

\section{Orerview}

After the Beamline Design Reriew (BDR), construction of the beamline may begin. It is expected that the bearmline designer will remain in close contact wich ALS suff during beamline construction. To onsure that the beamlins boing developed is installed in tho most effictent way, it is important that the beamline designer communicate details related to all aspects of the beamline to Als staff in a timely manner; as outlined below. Requests for modifications of anything approved during the BDR must be stbmitted to the Beamline Review Committee chair before the modification is made.

\section{Communication Items Daring Beamline Installation} The following information should be commusicared to ALS seff during beamtine construction (see Appendices $E$ and $F$ ior contact and scheduling Information).

a. Beamline instrumentation detalls, including the location of all vacuum valves, photon shucters, fast sensors, position monitors, ion gauges, residual gas analyzers, and motors.

b. Electrical requirements Including wireway layout, rack proille, cablesicerminations, and electrical power requirements. Beamline utilizy racks should be numbered as described in ALS Bsamline Rack Numbering Scheme (LSEF-107A), arailable from the ALS Liser Offite; see Appendix E for contact information. c. Vacuum requiremernts, ìnduding all vacuum needs refated to clean room facility, assembly of components, bakeous requirements, and installation.

d.Radiation stafey systems aro designed and Implemented by ALS staff and are unique to each beamline. The beamiline designer must inform the ALS staff of special requiraments.

e.Detils of the wquipment protection system (EPS) and brandhline control system (hardware and soltware). One of the most importane aspects is the installation and testing of the fast. valve sensors.

7. interlock thedkout procedures for the equipment protection system.

Note: The execution of these procedures may requite a specific secusence and mizy be carried one only on shutdown days.

g. A key-enable checklist must be provided by the beamitie designer in collaboration with ALS staff. This is a list of checks to be performed by the ALS Operations Coordinator each ime the beamline operator requess chat the beamline be enabled for operation. The first key-erable is performed as part of the BRR. Subsecuently, che bearnline will need to be enabled after eadh insance when it is zken off. line for maintertance. 


\section{Beamline Readiness Review}

\section{GENERAL INFORMATION}

\section{Defintition and Purpose}

Exch beamline must undergo a formal Beamline Readiness Review (BRR) to verify that the beamline has been built according to the design approved at the Beamline Design Review. The BRR has two parts-a review of documentation subminted to the BRC, and a walkchrough of the beamline to theck the installation prior to îrst-time operation. A sample copy of the Beanlfine Readiness Review Wolkthrough Procedure (BL 08-07) is induded as Appendx D.

\section{Whew is a BRR Condacted?}

A BRR for a new beamline will be conoucted after the beamline is installed, usually a few days before it is scheduled for first operacion. An operational beamline must undergo a 8RR whenover it is modified.

\section{Bati Walkthrough}

A comprehensive walkthrough inspection of the bearnllne is conducted by the ALS once all documentation and design requirements have been satlsfied. The BRR Walkchrough follows the ALS Beamline Readiness RewewWalkthrough Procedere (BL OQ-07). Items checked or exectuted during this protedur's inclusde:

I. Radiation shielding. The position and size of the bremsstrahlung shielding and exclusion zones are checked against the approved shielding drawings.
2 Radiation safety system (RSS) specific to each beamline. These systems are tested by ALS staff every six months.

3. Electriagl safecty qualification to ensure safery of olectrical components and wiring and to check for proper grounding and connections to vacuum vessels.

4. Mechanfol qualification to check for hazards relased to motorized motions and seismic safecy.

5. Vacuum qualification to ensure thac ion gauge readings and the resldual ges analyzer (RGA) scan conform to vacusem requirements arod that protection systems are in place.

6. Equipxnent proteccion systemn (EFS) qualitication, spacific to each beanlina.

7. Koy-enable procodure. The beamline is enabled for the first thene.

8. Radiation survey of the beamline to check for measurable levels of scattered bremsstrahlung radiation.

Authorization for Boutioge Operation Following a successful walkthrough, the ALS Director or designee gives authorization for routine operzton. Future moctfications to the beamline will require another BRR to examine the modified components. 


\section{INTRODUCTION}

This document describes the bremsstrahiung radtation shielding criteriz for insertion-device and bendmagnez beamline designs outside the storage ring shield walls. These eriterle are very similar to those proposed at the National Synchrotron Light Source (NSLS) at Brookhaven National Latoratory' and by earlier work here 23 the front-end shielding (inside the storage ring shield wall) has been designed such that beamline shielding designers need only know the source stze, the distence to the shiela wall, and the size of the penetration through the shield wall.

Each beamline must undergo a Conteptaral Design Review, a Beamline Design Revtew, and a Beamline Readiness Review by the ALS Beamline Reviow Committee. Beamline destgoers must prepare a package of documentation for these reviews. Among the most imporzant components of this documenta. tion package are bremsscrablung shiekling anamorphic drawings. These are drawings on which perpendicular directions have differing magnifications or scales. These drawings allow easy visualization and verification of ray tracings since beamline lengths are many times greater than their pertinent transverse dimensions, These drawings will be used guring the Beamline Design Review to ensure all bremsstrahlung radiation has been adequacely attenuated, and during the Bearnline Readiness Review to ensure proper installation of the shields.

As a point of clarification for previously written or inprogress ALS documentation, two terms are defined: primary shielding and secondary shielding. Primary shlelding is the shielding required to maintain the bremsscrahlung dose oucslde the shiels' wall to less than $\mathbf{4 0}$ mrem for a single worst-case catastrophic. event. This was the basis for the design of the cransition walls, and it is therefore applited to the design of the front-end shielding. Setcondary stielding Is the shielding required to reduce the norital, continuous gas brensstrahlung dose rates outside the storage ring shield walls to less then 200 mrem (2000 hr) per year. This document considers only secondary shielding and does noc address primary shielding (front-end shieldirg) or the design of personnel satecy shuterers.

\section{SOURCE SIZE}

During injection, the personnel safecy shutters on a bearnline are closed. Once they are opened, the major source of unwarranted radkation to the experiment area results from ilectrons scattering off residual gas molecules and creating highly forwardpeaked bremsterahlung photons. This rafiation is termed "gas bremsstrahlung." The source size is diccated by the cross-5ectional area of the electron beam-a few millimecers horizoncally and about three times smalter vertislly. However, for conservatism, it should be assumed that the minimum ans bremsstrahiung solurce size is a rectargie $4 \mathrm{~cm}$ $(1.6 \mathrm{~m}$. hilgh and $6 \mathrm{~cm}(0.4 \mathrm{in})$ wide, representative of the entire electron beam vafuum chamber exduding the antectramber. The location of the source depends on the type of fromt end:

Insertion-device fropt onds

- The source is to be located $2.7 \mathrm{~m}$ upstream of the outslde suriace of the storage ring exit flange for port 0 . This corresponds roughly to the entrance to the first bend magnet

Bend-magnet front ends

- The saurce for the first port should be located $3.5 \mathrm{~m}$ upstream of the autside surface of the storage ring extit ilange for port I, along the centerfine of the beam port This corresponds roughly to the downstream end of the first bend magnec

- The source for the second port should be located $3.3 \mathrm{~m}$ upstream of the ouside surface of the storage ting exit flange for port 2 , along the centerline of the beam port This corresponds coughly to the midpoinc of the second bend magnet.

- The source for the thind port shotid be located $3.5 \mathrm{~m}$ upstream of the outside surface of the storage ring exit flange for port 3, along the centerline of the beam port. This corresponds roughly to the downstream end of the second bend magnet. 


\section{SHIELD DUMENSIONS}

All lead radiation shidds required to reduce the os bremsstrahlung murs have at least $254 \mathrm{~mm}$ ( $10 \mathrm{O}$ in) of lend along the longitudinal patit and $50.8 \mathrm{~mm}$ ( 2 in) of lead as the minimum transwerse distance between the extreme ray and the outtside of the shield. ${ }^{5}$ This is shown th Figure I. No partial credit is taken for rays passing through less than the full $254 \mathrm{~mm}$ lead equivalent in any one shietd. The $254 \mathrm{~mm}$ leadequivalent requirement is moant to apply to all baanline designs, whether they are bend-magnat or insertion-device beamlines, Beamlines which have been bent by bearnline components such as monochromators, and whith penetrate the shield wall above or below the belly band, may not require additional shielding ourside the shield wall tf the frontend shielding is shown to be adequate.

Other shielding materials may be used if shown to be of equivalent thickness. The equivalent lead thickness is calculated as the ratio of the menn free paths at the Compton-minimison in the phowon cross secrions.

Gas bremstrathlung dose rates are directly proportional to the length of the straight section triversed by the electron beam, Dus to the shorter drift length of bend-magnet beamlines, lower dose rates dewnstream would be anticipated. However, for conservatism, consistency, and to elliminate any possibility of crosstalk between insertion-device and bend-magnet bearmines, the $254 \mathrm{~mm}$ lead requirement appliso to both.

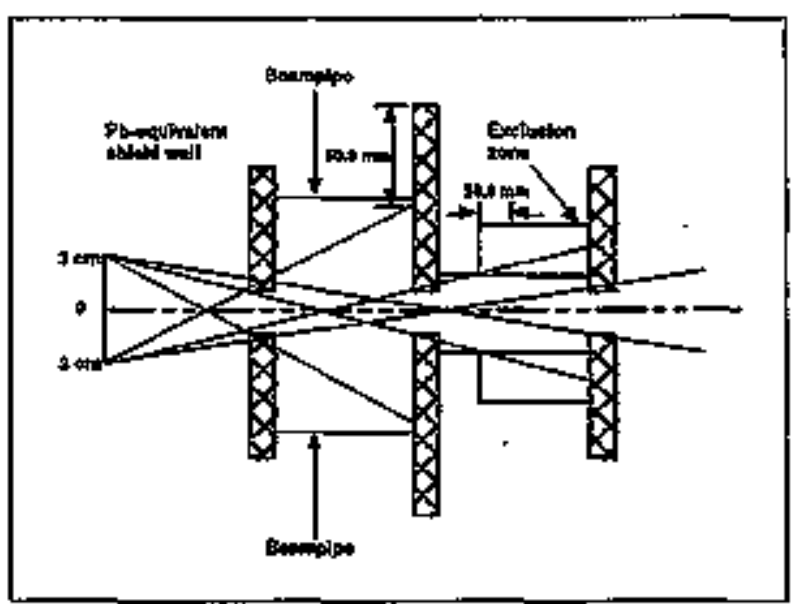

Figare I. Exomple of exdeme roy layout plan view for o beamilne (azimuthally symirietric).

\section{ANAMORPHIC DRAWING}

The anamorphite drawing is tsed by the Beamline Review Committee to verify the adequacy of the shiekding and to check the location of all shielding once the beamline has been constructed. An example of an anamorphic shielding drawing is shown in Figure I. All drawirgs should include a Beamline Review Committee approval box, elther drawn or creaced by tose of an applique that will be availatle at the Als. The drawing should stiow the extreme trajectories of bremstrrablung $x$ rays from the souree model described atove, through the penetration it shield wall, and then through the beamline collars/shields to the backstop. As describod above, all bremsstrahlung shields should be $254 \mathrm{~mm}$ thick and extreme rays should be no less than $50.8 \mathrm{~mm}$ from the outside of the shielo. Extreme rays are those rays that define the extent of the bremsstrahiung cone (one set for plan views, one set for elevation wews) which passes through the required $254 \mathrm{~mm}$ lead equivalent (see Figure 1).

The divergence of the bremsstrahlung radiation for bearnline shielding is defined by the size of the source (given abovo) and the ofstance from the source to the inside comer of the pesietravion through the shiold wall. The drawings muse inchded both plan and elevation vitwrs. The ollevation view should represent the view from the most acessible side of the beamlina. Each shoutd fit on a single, large, stanchard-sites sheet of paper such as an E-size drawing. The drawing should start from the bremsttrathlung sourze and extend to a point where all bremsstrahiung $x$ rays have been attenuaced by the required lead equivalent of $254 \mathrm{~mm}$. Note that in some ceses this may extend to a huch backstop at the end of the boamline, whoreas in otier cases it may extend only to the point at which the synchrotron radiation has been deflected from the bremsstrahlung cone and terminated in a load shield wall.

When preparing the drawing, all bremsstrahlung shields must be labeled and most show trentwerse and Iongitudinal dimensions, as well as the distance from the source point, the storag* ring shield wall, and the beampipe conterline. Both the longitudinal and transverse scales should bs indicated. All bremsstrablung shields should haqve unique designations associated with tisem. 
The labels for the bremsstratherng shielding and exclusion zoness should follow the format

B(number of branchtine)_BSxx (for shieking) B(number of branchline),EZxO (for exchusion zones)

Where $x \alpha$ indicates the mimber of the shield or exclusion zone The bremsstrahlung shieids and exdusion zones should be numbered sequentally starting from the storage ring. For example; B7.0I_BSOI speciffes the first bremsstrinlung shiekd on branthline $I$ of the undulator beamline in scorage ring sector 7, and B9,3.1_EZ8 specifies the eighth exclusion zone on branchline I of the bend-mationt. beamline coming off of the fourth port in storge ring sector 9 .

\$hiekds should have their composition and density specified either individually or in a general note. Shielding should be desighed such that it anot be tradvertently moved by simp\}o means feg., arrying awry lead bricks). Lead shiekds should be coated to prevent excesswe lead exposures. The ALS Environmental Health and Safioty Program Manager should be notiffed before installation of all lead shiekds (seis Appendix $E$ for contact information). All shields should comply with seismic safety rules and proce. dures eseablished in the LBNL Heath \& Safety Manual (PUB-3000). Exmples of ALS anamorphic drawings tan be requitestad from ALS Mechanical Engineering.

\section{EXTREME RAYS}

The extremp-ray bremsstrahlung cone, shield wall, beamptipe, and hutches/endscasions should be clearty identified on all yiews. In any area where the bremsstrahtung cone is outside the beampipe or shiekt, access must be tinited. Such an area is colled an exclusion zone.

Physical barriers preventing access to an exchustion zonle must be constructed and may consist of mater. als such as corrugated metal or Plexiglas to ellminate possible exposure to bremsstrahlung $x$ rays, All exclusion zones should be clearly labeted on the anamorphic drawing and their overall dimensions should be indicated. It is acceptable to use the beampipe laself as an exclusion zore. In cerrain areas it may be desirable to oversize the beampipe to include all extreme rays. However, this practice is not recommended through the shiold wall bectust it may resulc in an unnecesstarily large opening in the transition wall.

A sketch of an extreme-ray brensstrahlung cone is shown in Figurs 2. Note that the extreme rays are desined from the inside corner of the lead shield. No partial credit is taken for rays passing thicough less than the full $254 \mathrm{~mm}$ lead equivalent in any one shield. in addition, no credit is taken for knger path length through the lead due co the ray's oflique incident angle (with appears grenty exaggerated on the anamorphic drawing. As mentioned earlier, the

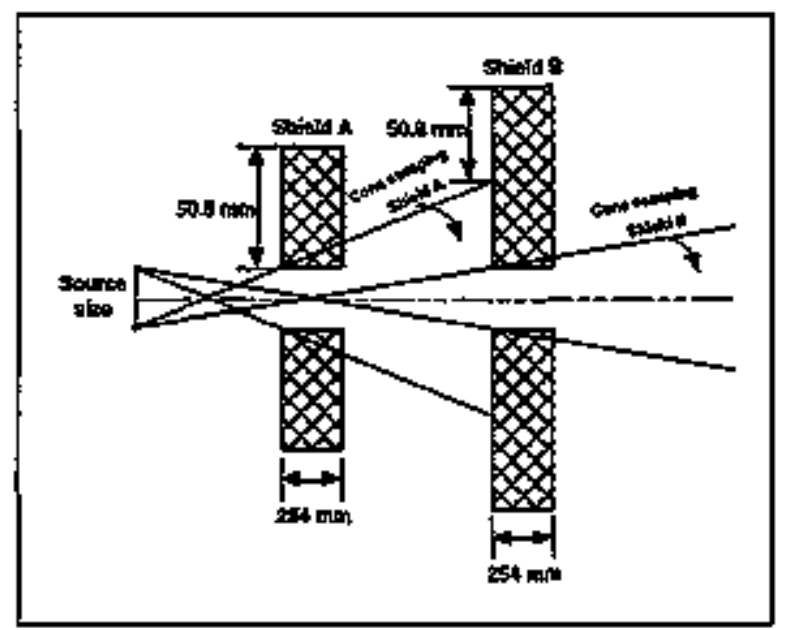

Figure 2. Example of extreme rays through two bremsstralikeng rodiotion shiekds. 
trartsyerse distance from che extreme ray incident on a shiegd to the outside of the stield should not be less than $50.8 \mathrm{~mm}$. As can be seen from Figure 2, exclusion zones will most often be required just upstream of shields where the bremsstratulung conq has reached fts largest transverse extent The distance from the extreme ray to the outside of the exchusion zone should also not be less than $50.8 \mathrm{~mm}$ (2 in). The "2 inch" rule is meant to apply in cases where the extrome ray has been intercepted by a shield, flange, or beampipe, and does not apply when the extreme ray is contained inside the beanipipe.

Figure 3 shows that sometimes simple plan and elevation views are not enough to idesntify exclersion zones. It is the responsibitity of the destgner to tidentify all probiem areas.

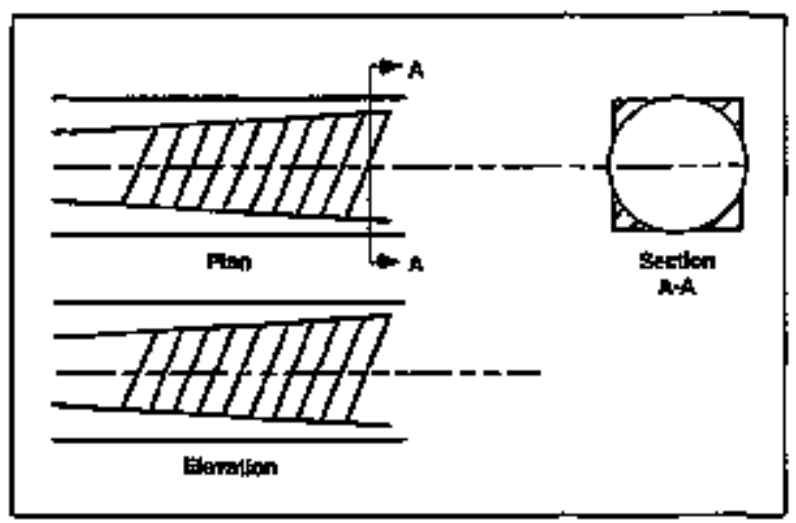

Figure 3. Plan and elevotion wiews show the bremsstrohtang core clearly confirsed while the section Wew shows a partion of the core artide the beampitie, requiring the identificotion of an additional exckusion zone.
R.j. Donahue

july 1993, revised May 1996.

I R. Stefan, NSLS-BNLL, personal communicacion.

2 T. Warwikk. "Bremsstrahlung Collimation and Shlelding for ALS US and UB Beaminnes;" (LSBLLOSBA).

${ }^{3}$ T. Warmick, oc al. "Radiation Safecy Shutters, Collimation and Shielding for ALS Beamlines," (LSBt,073).

- 4 R.J.Donahute, "Gas Bremsstratikng Estinates for Als Hitch Backstops," (L8L-J62).

5 P. Stefan, op.cit 


\section{Appendix B - Advanced Light Source Vacuum Policy and Vacuum Guidelines for Beamlines and Experiment Endstations (LSBL-280)}




\title{
Advanced Light Source Vacuum Policy and Vacuum Guidelines for Beamlines and Experiment Endstations Revision 2 . .
}

\author{
Beamline Review Committee \\ August 22, 1995 \\ (Suparsedas LSBL \#116)
}

\section{Contents:}

i. Introduction

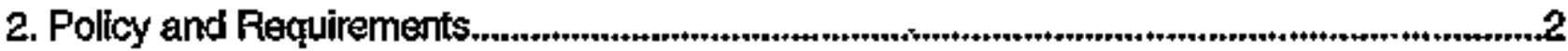

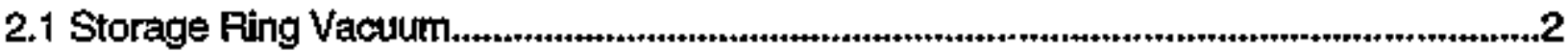

2.2 Means Used for Ensuring the Quality of the Storage Ring Vacuum..........................3

2.3 ALS Vacuum Requirements .........................................................................................3

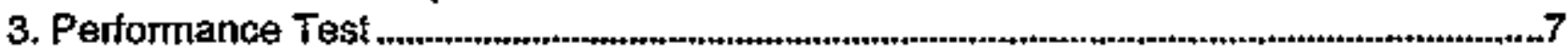

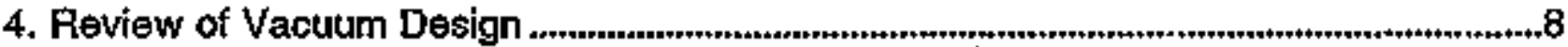

5. Vaculari Guidelines for Bearnline and Endstation Experiment

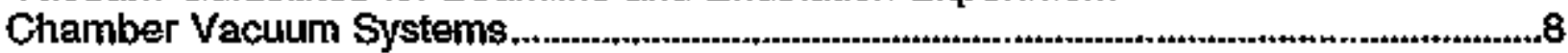

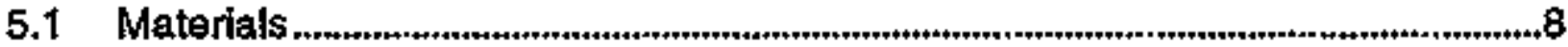

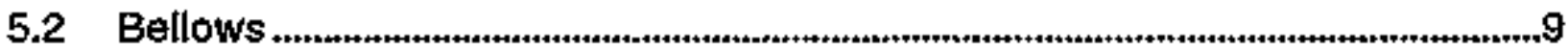

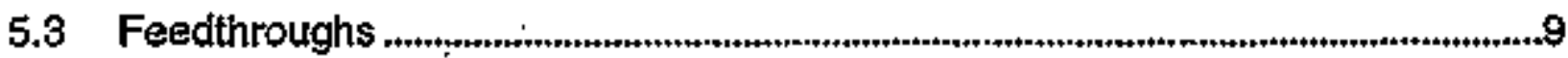

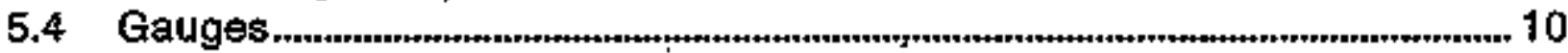

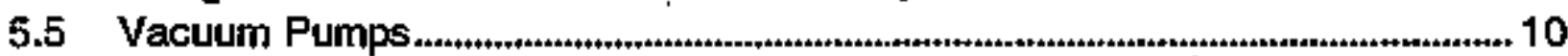

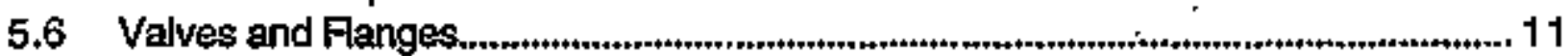

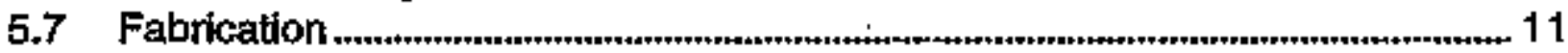

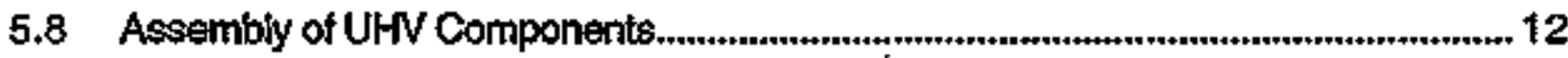

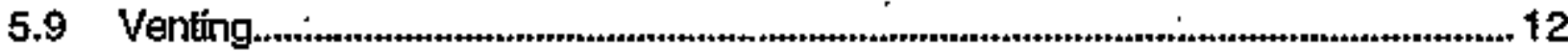

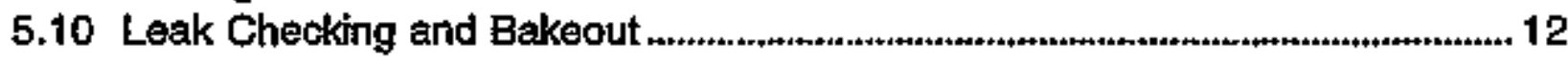

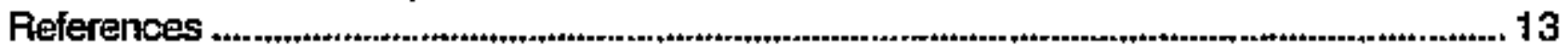

Abbreviations:

BRC Beamline Review Commiltes

CDR Concepltual Design Review

EPS Equlpment Protection System

LCW Low Condisctivity Water

PRT Participating Research Tean

PSS Personnet Salety Shutter

RGA Residual Gas Anahzer

RSS Radiation Safety System

UHV Ultra High Vacium

Front end Front end components serve to define a beam aperture for synchrotron radiation and provide necessary beam ondoff, radiation safety, and vacuum.jsolation systems for each bearniline for both insertion devioe and bending magnet sources. The front end components generally reside inside the storage ring shielding and physically connect the ring vacuum charnber to the first valve of the beamline. 


\section{Introduction}

The purpose of this document is to:

1. Explain the ALS vacuum policy and specifications for beamlines and experiment endstations.

2. Provide guidelines related to ALS vacuum policy to assist in designing beamlines which are in accordance with ALS vacuum policy.

This document supersedes LSBL-116.

The Advanced Light Source is a third generation synchrotron radiation source whose beam lifetime depends on the quality of the vacuum in the storage ring and the connecting beamtines. The storage ing and most of the beamlines share a common vacultm and are operated under uitra-high-vacuum (UHV) conditions. All endstations and beamline equipment must be operated so as to avoid contamination of beamline components, and must include proper safeguards to protect the storage ring vacuum from an accidental break in the beamline or endstation vacuum systerns.

The primary gas load during operation is due to thermal desorption and electron/photon induced desorption of contaminants from the interior of the vacuum vessel and its . components. The desorption rates are considerably higher for hydrocarbon contamination, thuts considerable emphasis is placed on eliminating these sources of contaminants.

All vacuum components in a beamline and endstation must meet the ALS vacuum specifications. The vacuum design of both beamlines and endstations must be approved by the ALS Bearnline Review Committee (BRC) before vacuum connections to the storage ring are made. The vactum design is first checked during the Beariline Design Review (BDR) held before construction of the beamline equipment begins. Any deviation from the ALS vacuum specifications must be approved by the BRC prior to installation of the equipment on the ALS floor. Any modification that is incorporated into a vacuum assembly without the written approval of the BRC is done at the user's risk and may lead to rejection of the whole assernbly.

Note: All pressure values described in this document are $\mathrm{N}_{2}$ equivalent values, l.e., all . pressures are measured setting the sensitivity in the ion gauge controller for $\mathrm{N}_{2}$ gas.

\section{Policy and Requirements}

\subsection{Storage Ring Vacuum}

The ALS storage ring vacuum system consists of atl-metal, chemically cleaned, bakeable components. It generally operates at pressures of less than $2 \times 10^{-10} \mathrm{mbar}\left(2 \times 10^{-8} \mathrm{~Pa}\right.$, $1 \mathrm{mbar}=0.76$ torr) without beam, and at pressures of less than $1 \times 10^{-9} \mathrm{mbar}\left(1 \times 10^{-7}\right.$. Pa $)$ with beam. 


\subsection{Means Used for Ensuring the Quality of the Storage Ring Vacuum}

The main objective of the ALS vacuum policy is to ensure that the vacuum connection of any beamline and its associated experiment endstations will not degrade the quality of the storage ring vacuum. Generally, beamlines may be separated into two broad categories. The ALS vacuum requirements differ for each category.

Category 1: UHV beamlines that share the same vacuum as the storage ting.

Category 2: Non-UHV beamlines in which the vacuum is completely or partially separated from the front end components and storage ring vacuum ty using either a window or differential pumping.

For both categories, the storage ring vacuum integrity is ensured by checking that the following three items meet the requirements described in detail in Section 2:

a. The base pressure in vartous parts of the beamline.

b. The contribution of high mass gases to this pressure at appropriate places as checked by the residual gas spectral analysis (RGA), if and when required.

c. The vacuum Interlocks which protect the storage ring in the event of accidental vacuum failure.

For non-UHV beamlines, it may also be necessary for users to provide calculations ensuring that, in case of a vacuurn failure, the vacuum interlocks will adequately protect the ALS vacultrn integrity.

All beamlirie components are required to be manufactured according to the guidelines described in Section 5 of this document.

\subsection{ALS Vacuum Requirements}

This section describes the three requirements that must be met for both categories of beamlines:

\subsubsection{UHV Beamlines (Category 1)}

This category of beamline normally shares the same vacuum as the storage ring and operates under UHV conditions.

(a) Pressure Requirement

The base pressure in all vacuum components that will be directly exposed to the storage ring vacuum must be less than $2 \times 10^{-9} \mathrm{mbar}\left(2 \times 10^{-7} \mathrm{~Pa}\right)$ and it is expected that this pressure requirement will be maintained during the nomal operation. However, during the initial scrubbing period of the beamline components with synchrotron radiation, an increase in pressure by an order of magnitude may be allowed, with the exception that at the storage ning exit port, the pressure must be $2 \times 10^{-9}$ mbar or less at all times. 
(b) Residual Gas Analysis (RGA) Requtrement

The beamline or the vacutum system must be checked for gas analysts, using a residual gas analyzer (RGA), before it is opened to the storage ring vacuum. For beamline qualification, the RGA check is generally done downstream of the first vacuum isolation valve outside the shielding wall. For experiment chambers, the test may be done in the chamber itself or in the first beamline chamber upstream of the experiment system. The RGA used must be sensitive to a partial pressure of $i \times 10^{-14}$ mbar $\left(1 \times 10^{-12} \mathrm{~Pa}\right.$ ) or less and be capable of scanning in a range of at least 1-200 atomic mass units (AMU). The RGA scan must indicate that the sum of the partlal pressures of gases having a mass of 46-and-greater (46 AMU) does not exceed $1 \times 10^{-11}$ mbar $\left(1 \times 10^{-9} \mathrm{~Pa}\right)$.

All new systems as well as beamlines that have been changed and brought up to air must be checked to ensure that they meet the above vacutum and RGA requirements before they are allowed to be opened to the storage ring vacuum.

However, under certain conditions as determined by the ALS vacuum group, a waiver for $R G A$ requirements may be provided to a beamline andior experiment endstation which normally operate under UrV condition. These conditions include opening of a beamline vacuum chamber or experitinent chamber for minor changes, such as replacing a burnt ion gauge filament, and changing solid samples which have similar outgesing characteristics. In all cases, a waiver will only be granted to vacuum systems which have previously been qualified at least once for meeting RGA requirements, and have achieved a pressure below $3.0 \times 10^{-10}$ mbar $\left(3 \times 10^{-8} \mathrm{~Pa}\right)$ after necessary pumpdown and bakeout.

In any case, it is at the discretion of the ALS Vacuum Group or BRC to make the decision regarding a watver.

(c) Vacutum Interlocks Requirement (Protection in the Event of Vacuum Failure) The storage ring vaculim is protected from accidental vacuitum fatlures by fast sensor interlocks in case of catastrophic faliure, and by ion gauge pressure interlocks in the event of a relatively slow leak.

Each beamline has one or two fast sensors. The recommended distance for the fast sensor to be from the fast valve is $10 \mathrm{~m}$ or more, to allow enough time for the fast valve to close before arrival of the gas wave front in the event of a vacuum break. The fast sensors are interlocked with the front-end valves and shutters. The front end contalns one or more all-metal isolation valves, a fast-closing valve, and a pneutmatically actuated photon shutter (which is between the storage ring and the fast valve).

If there is an accidental break in the beamline vactum system, a fast-response vacuum sensor will detect the break, and the fast valve will close in less than $10 \mathrm{~ms}$. This also requires the stored beam on insertion device beamlines to be dumped to protect the fast valve from being exposed to the large power of synctrotron radiation. The primary vacuum isolation valve between the storage ring and the beamline will pneumatically close and seal the ring vacuum in about 3.5 seconds. The photon shutter located between the storage ring and the 
isolation valve will also close. These components are controlled by the Equipment Protection System (EPS) for the front end and the beamline. More details related to the EPS are given in "ALS Beamline Design Requirements, "PUB-3114.

All vacuum interlocks on beamline components supplied by experimenters must meet ALS design specifications. The ALS will advise users about vacuum requlrements and interlock procedures for monochromators and endstations. Generally, these should operate under UHV conditions similar to those of front ends and the storage ring. Electrical connections between user vacuum interlocks and front-end components will be made and tested by authorized ALS staff. Fast . sensors should be installed outside of the shielding wall and downstrearn of the monochromators in positions approved by the BRC.

For each beamline there must be at least one fast sensor located downstream of the first isolation valve near the outside of the shield wall. Another fast sensor may be located upstream of the endstation (a stitable place would be downstream of an exit slit or any other conductance-limiting component).

The fast sensors are set as follows:

Fast Sensor Set Point: A set point of $1 \times 10^{-5}$ mbar $\left(1 \times 10^{-3} \mathrm{~Pa}\right)$ protects against catastrophic failure. If the pressture at any sensor is above this value, the corresponding fast valve/s is triggered, which simultaneously closes the photon shutter and the isolation valve. On insertion device beamlines, the stored bearn must be dumped to protect the fast valve from being exposed to the large power of synchrotron radiation, as well as to protect personnel from bremsstrahilung radiation.

In addition, ion gauges (located on either side of the isolation valve) are interlocked (using ion gauge controllers at set values) to protect the storage ring. against high pressure due to excossive outgasing, a slow leak, power failure, etc.

The ion gauge controller interlock set points are such that: Ion Gasge Controller Set Point: Set at $2 \times 10^{-8} \mathrm{mbar}\left(2 \times 10^{-6} \mathrm{~Pa}\right)$ or lower such that, if the pressure exceeds this value, the isolation valve upstream of the ion gauge will close and seal. The fast valve may remain open. The stored electron bearn will not be affected.

Please note that the above pressure values set for interlocks are higher than the normal operating pressures.

If any one of the intertocks is triggered, the isolation valves along with other shutters will close. They should not be re-opened uniess:

1. The pressure in that section is below the pre-approved limit, and

2. The pressure in the front end is below $2 \times 10^{-9}$ mbar $\left(2 \times 10^{-7} \mathrm{~Pa}\right)$.

If the fast sensor is triggered, the operations coordinator will have to be contacted before beamline can be brought back on fine. 


\subsubsection{Non-UHV Beamlines with Vacutum Window/s or a Differential Stage (Category 2)}

A beamline downstream from the front end may operate in a helium atmosphere or oilfree rough vacuum under the following conditions:

i. A window capable of withstanding at least 1 atmosphere pressure isolates the storage ring vaculum from the beamline vacuurt.

ii. A thin window with appropriate interlocks isolates the storage ring vacuum from the low vacuum side of the beamline.

iii. Efficient differential pumping allows downstream components to operate at higher pressure without affecting the low vacuum requirement of the front end.

The design of these devices must be approved by the BRC.

(a) Pressure Requirement

The base pressure in all vacuum components upstream of non-UHV equipment which is directly exposed to the storage ring vacuurn must be jess than

$2 \times 10^{-9}$ mbar (less than $2 \times 10^{-7} \mathrm{~Pa}$ ). This pressure requirement must be met at all times during the normal operation of the beamline.

However, during the initial scrubbing perlod of the beamline components with synchrotron radiation, an increase in pressure by a maximum of an order of magnitude may be allowed.

The maximum pressure downstream of the vacuum window or differential stage or conductance limiting component may be of, any sub-atmospheric value, as long as the above condition is always maintained.

(b) Residual Gas Analysis (RGA) Requirement

The vacuum system is to be tested using a residual gas analyzer (RGA) upstream of the vacuum window or the differential stage. The RGA used must be sensitive to a partial pressure of $1 \times 10^{-14}$ mbar $\left(1 \times .0^{-12} \mathrm{~Pa}\right)$ or less and be capable of scanning in a range of at least 1-200 atomic mass units (AMU). The RGA scan must indicate that the sum of the partial pressures of gases having.a mass of 46and-greater (46 AMU) does not exceed $1 \times 10^{-11} \mathrm{mbar}\left(1 \times 10^{-9} \mathrm{~Pa}\right.$ ). The RGA scan must be performed by the ALS Vacuum Group for each new experiment before the isolation valve is opened. For experiments involving materials of potential hazard, the RGA will be monitored either continuously or intermittently during operation (at the discretion of the ALS beamline coordinator and or vacuum group\}.

(c) Vacuum Interlock Requirements (Protection in the Event of Vacuum Failure) The storage ring vacuum is protected from accidental vacuum fallures by fast sensor interocks in case of catastrophic failure, or by ion gauge pressure interlock(s) in the event of a relatively slow leak.

For non-UHV beamlines, one fast sensor must be installed and it is recommended that two be installed. The first must be downstream of the first isolation valve outside the shield wall. The second sensor should be at a place with potential 
vacuum break, such as just upstream of a vacuum isolating window or differential stages.

All vacuum interlocks on beamline components supplied by experimenters must meet ALS design specifications. Electrical connections between user vacuum interlocks and front end components will be made and tested by authorized ALS staff members.

Both fast sensors and ion gauge controllers are set as follows:

1. Fast Sensor Set Point: If the pressure at any sensor is above $1 \times 10^{-5}$ mbar . ( $1 \times 10^{-3} \mathrm{~Pa}$ ), the corresponding fast valve/s is triggered, which simultaneously closes the photon shutter and the isolation valve. On tinsertion device beamlines, the stored beam must be dumped to protect the fast valve from being exposed to the large power of synchrotron radiation, as well as to protect personnel from bremsstrahlung radiation.

ii. Ion Gauge Controller Set Point: Set at $2 \times 10^{-8} \mathrm{mbar}\left(2 \times 10^{-6} \mathrm{~Pa}\right)$ or lower on all ion gauge controllers measuring the pressure upstream of the vacuum isolation window or differential stage. If the pressure exceeds this value, the isolation valve upstream of the ion gauge will close and seal. The fast valve will remain open. The storage ring will not be dumped. Ion gauges located downstream of the window or differential stage may be set at any value, provided the above conditions are met.

Please note that the above set points for interlocks are considerably higher than the nomal operating pressures.

If any of the interlocks is triggered, the isolation valves and the other shutters will close and must not be opened unless:

1. The pressure in that section is below the pre-approved limit, and

2. The pressure in the front end is below $2 \times 10^{-9} \mathrm{mbar}\left(2 \times 10^{-7} \mathrm{~Pa}\right)$.

If the fast sensor is triggered, the operations coordinator will have to be contacted before beamline can be brought back on line.

\section{Performance Test}

The beamline and/or front end must be checked for compliance with the three ALS vacuum requirements (Vacuum, RGA scan, and Vacuum Interlocks) by the ALS Vacuum Group, if:

i. The front end is to be opened to the storage ring for the first time.

ii. The branchline is to be opened to the front end for the first time.

iil. Any part of the beamline is changed or brought up to air and is ready for reconnection to the storage ring vacuum. 
For UHV bearnlines, the RGA requirement may be waived under special circumstances. (When it is decided by the ALS Vacuum Group and/or BRC that checking the RGA requirement is unnecessary and would not provide information of any practical use. See Section 2.3.)

\section{Review of Vacuum Design}

The vacuum design of each beamline is reviewed by the BRC during a beamline design. review. The experiment group (PRT) must demonstrate that the design witi not degrade the quality of the storage ring vacuum and that It follows the ALS vacuum policies outtined in this document. The PRT should submit:

i) Beamline assembly drawings or suitable sketches to scale.

ii) A list of vacuum components and materials of construction.

iii) A list of pumps, their specifications, and locations.

iv) Information related to vacuum interfock system.

v) Caiculations showing that in case of a vacuum failure, the vacuum interlock will adequately protect the ALS vacuum integrity.

The PRT must obtain BRC approval before ordering any non-standard, non-UHV vacuum components and before fabricating any beamline components.

Approval of a PRT beamline design by the ALS Beamline Review Committee does not allow the PRT group to bypass the performance tests outlined in Section 3.

\section{Vacuum Guidelines for Beamline and Endstation Experiment Chamber Vacuum Systems}

ALS beamlines must have all-metal, hydrocarbon-free front end components. UHV design criteria must be used for the hardware downstream of the front end, if the hardware and the front end share a common vacuum. The BRC must approve any deviations from the requirements in this section.

The following is a partial list of items which will help in developing a UHV system compatible with ALS requitements. Questions or requests for additional information should be directed to the BRC or the ALS Vacuum Group.

\subsection{Materials}

Standard UHV-compatible materials must be used in all beamlines sharing the same vacuum as the storage ring. The following is a list of materials that are and are not 
acceptable for UHV. Any material not listed must be approved.

\begin{tabular}{|c|c|c|}
\hline Acceptable & Not Acceptable & Marqinal \\
\hline $\begin{array}{l}\text { Pure metals: } \\
\text { aluminum } \\
\text { copper (incl. Glidcop) } \\
\text { gold } \\
\text { silver }\end{array}$ & \multirow{5}{*}{$\begin{array}{l}\text { Żinc- and cadmium- } \\
\text { bearing metals and } \\
\text { alloys are not UHV- } \\
\text { compatible. } \\
\text { Organic materials } \\
\text { are not permitted } \\
\text { unless they are } \\
\text { specifically } \\
\text { authorized by the } \\
\text { BRC. }\end{array}$} & $\begin{array}{l}\text { Stainless Steel: SS } \\
\text { containing excessive } \\
\text { amounts of sulfur or } \\
\text { selenitum must be } \\
\text { avoided. }\end{array}$ \\
\hline $\begin{array}{l}\text { molybdenturn } \\
\text { tungsten } \\
\text { titanium }\end{array}$ & & \multirow{4}{*}{$\begin{array}{l}\text { Elastomers such as viton } \\
\text { may be allowed in the } \\
\text { seat of a gate valve with } \\
\text { metal bonnet seals. } \\
\text { These valves are only } \\
\text { allowed in the places } \\
\text { where there is no } \\
\text { chance for the elastomer } \\
\text { to be exposed to } \\
\text { radiation. }\end{array}$} \\
\hline $\begin{array}{l}\text { Stainiess Steel: } \\
300 \text { series (preferred } \\
\text { types are: } 304,316 \text {, } \\
321 \text {, and } 347) \text {. }\end{array}$ & & \\
\hline $\begin{array}{l}\text { Alloys: } \\
\text { Ampco } 18 \\
\text { beryllium copper } \\
\text { inconel } 600 \text { or } 718 \\
\text { mu-metal } \\
\text { Kovar }\end{array}$ & & \\
\hline $\begin{array}{l}\text { Cetamics: } \\
\text { Alumina ceramics } \\
\text { sapphire } \\
\text { machinable glass } \\
\text { ceramic }\end{array}$ & & \\
\hline
\end{tabular}

\subsection{Bellows}

Both welded and formed belows are allowed, provided they are manufactured using UHV standards.

Since welded bellows are made of thin stainless steel diaphragms welded on the inside and outside diameters to form a series of convolitions, proper UHV techiquues are required during manufacturing to avoid trapping of hydrocarbons or contaminants in the crevices of the convolutions. it is strongly recommended that the bellows be chemically degreased and baked in vacuum before being installed in the beamline.

Formed bellows are relatively easy to clean, but must be fabricated for UHV applications.

\subsection{Feedthroughs}

Ceramic-to-metal type electrical feedthroughs are allowed for making electrical connections into the vacuum system. No glass-to-metal 'feedthroughs are permitted. Voltages and current carried through the feedthroughs must not exceed the 
mantfacturer's ratings. Extemal covers and cable restraint are required to protect against the accidental breaking of ceramics (which is a major cause of vacutum failure).

Belfows-type mechanical rotary and linear feedthroughs manufactured for UHV applications are allowed. Feedithroughs with a single elastomer seal are not permitted. However, two-stage differentially pumped feedthroughs with elastomer seals may be allowed, with approval by BRC.

\subsection{Gauges}

Glass ionization gauges are not permitted in beamlines. Nude ionization gauges with ${ }^{\text {* }}$ two independent filaments and controllers with electron bombardment degassing capability are recommended. It is recommended that the cable connection to the gauge head be bakeable to $200^{\circ} \mathrm{C}$ and have an enclosed connector or cable restraint. Cold cathode, thermocouple, or Vactron gauges may be allowed, if they meet UHV requirements.

\subsection{Vacuum Pumps}

Any one or combination of the following primary pumps may be used:

Sputter-ion purnps: Ion pumps (either diode, triode, or differential ion) are the most reliable pumps for UHV use. Differential ion pumps which contain both titanium and tantalum filaments are recommended, due to their ability to pump inert gases.

Titanium sublimation pumps (TSP): TSP, in combination with ion pumps, are very effective. in creating UHV.

Non-evaporable getter (NEG) pumps: NEG -pumps are made of UHV-compatible, active metals which pump by chemisorbing gases.

Cryo pumps: May be used with appropriate isolation valves and intertocks, which must be approved by the BRC.

Turbomolecular-purnps: It is strongly recommended that both the turto and the backing pump be oil-free. They must be equipped with appropriate interlock isolation valves for protection in case of pressure and/or power failures. The use of a.turbo purnp as a primary pump in the beamline is discouraged and must be approved by BRC. A turbo pump system (preferably oll-free) with appropriate interiocks may be used in the endstation experimental chamber.

Diffusion pumps: These are not permitted due to their inherent risks of oll contamination.

Roughing Pumps: Only oil-free mechanical pumps may be used as roughing purnps. Under extreme circumstances where no altemative exists, an exception-may be given by the BRC. During the initial rough-pumping and/or bake-out of the beamline, turbo pumps, cryo pumps, soption pumps and or any other oil-free pumps as approved by the BRC or Vacuum Group may be used. This is allowed only when the front end isolation valve is closed. They may also be used at the endstations. When used at an endstation, a pump 
must be equipped with appropriate interlock isolation valves for protection in case of a pressure and/or power failure.

Backing Pumps: It is strongly recommended that only oil-free mechanical pumps be used as backing pumps. Under extreme circumstances where no altemative exists, an exception may be given by the BRC.

The vacuum requitrements as outlined in Section 2 must always be satisfied.

\subsection{Valves and Flanges}

All-metal, bakeable UHV valves, flanges, and seals are acceptable. Flanges with elastomer seals are not allowed in the beamline. Metal bonnet valves with elastomer seals are not allowed in beamlines where the seal may be exposed to direct synchrotron radiation. If approved by the BRC, they may be used in places where radiation exposure is not a problem.

\subsection{Fabricațion}

Fabrication of any component which becomes part of the vacusum environment of the bearnline directly exposed to storage ring vacuum must be done using UHV compatible materials and following UHV-accepted techniques, including:

Surface Preparation: No machining or polishing operation which might result in contaminants being embedded in the material should be used. All tapped holes should be vented.

Machining Lubrication: No cutting lubricant may be used which results in contamination that cannot be removed by standard cteaning methods. The use of cutting fluid containing sulfur or siltcone compounds is not recommended. Refer to ALS engineering notes LSME-479 (Light Source Beamlines Vacuum System-General: Fabrication, Handing, and Cleaning Parts Before Brazing, Stress-Relief Annealing, or Preliminary Bake-Out at High Temperatures for Ultra-High Vacuum Service) and LSME-500B (Light Source Beamlines Vacuum Systems General: Fabrication, Cleaning, ard Certification of Stainless Steel Vacuum Chambers for Weldments for UHV) for the recommended procedures.

Water Cooled Optics: Vacuum-to-water joints are not permitted in the ALS beamline vacuum systems, unless there is an intermediate guard vacuum. Refer to ALS fechnical note M7184 (Mirror Brazing Technique). Vacuum-to-water joints must be avoided as much as possible in the user's' vacuum chamber systerns.

Chemical Cleaning: All UHV components must be vapor degreased, electropoilished, and/or chemically cleaned before installation in the beamline. Refer to ALS technical note LSME-421A (Light Source Photon Beam Lines-BNL/NSLS XI Beamine Mirror System M-Zero Mlror System: General Cleaning and Brazing Procedures for Furnace-Brazed U.H.V. Parts). 


\subsection{Assembly of UHV Components}

It is highly recommended that assembly of UHV components take place in a clean room or in a clean laminar flow hood. There are many sources of contaminants. The single largest sources during assembly are perspiration, body oils, hair, perfume, etc. Thus, the use of clean gloves, face masks, lab coats, and head covers during assembly is recommended.

Lint-free paper or cloth wipes are recommended for use with UHV parts. Ethanol should be used as a wiping solvent, if necessary.

All UHV components which may get exposed to contaminants should be protected by clean, oil-free aluminum foil or lint-free paper.

No cadinium-plated, brass, lead, or wood tools should be used during assembly.

If a chamber is to be opened to air and cannot be moved to the clean room, it is recommended that the chamber be purged continuously with dry nitrogen gas. A liquid nitrogen source is the best choice to get the quantities of dry nitrogen required. The ALS will provide such a source.

\subsection{Venting}

If a UHV chamber is to be vented, dry nitrogen should be used for venting the systern. A pressure relief valve is required in the venting system, especially to protect view ports from exploding. A safe recommendation for the relief pressure valve setting is $30 \mathrm{mbar}$ ( $0.5 \mathrm{psi}$ ) above atmosphere (a recomrnendation by Varian).

\subsection{Leak Checking and Bakeout}

It is highly reconmended that the whole system be leak-checked before going through the thorough bakeout. The recommended temperature for bakeout of a stainjess steel chamber is $200^{\circ} \mathrm{C}$. There may be other constraints which may limit the bakeout femperature to a lower value.

For a system which may give high outgassing loads, it is generally recommended that a nitrogen bake be done, followed by a vacuum bake. During a nitrogen bake, dry nitrogen gas from an evaporated liquid nitrogen source is pumped through the assembly while the components are heated. 


\section{References:}

For further cetails conceming ultra-high vacutum practice, the user may consult:

1. Practical Vactum Techniques, by W.F. Brunner and T.H. Batzer, published by Krieger, 1974.

2. A User's Guide to Vacum Technology, by J.F. O'Hanlon, published by John Wiley \& Sons, 1980.

3. High Vacuum Technology: A Practical Guide, by Marsbed H. Hablanian, publishedi by Marcel Dekker, Inc., New York, 1990.

4. Basic Vacuum Practice, Third Edition, Varian Vacuum Products Training Department, Varian Associates, 1992.

5. Vacuum Policy for ALS Beamlines and Experimental Systems, by R.C.C. Perera, K.D. Kennedy, J.R. Meneghetti, LSBL-116

6. Light Source Beamlines Vacuum System-General: Fabrication, Handling, and Cleaning Parts Before Brazing, Stress-Relief Annealing, or Preliminary Bake-Out at High Temperatures for Uitra-High Vacuum Service, by D. DiGennaro, LSME-479.

7. Light Source Beamines Vacuum Systems General: Fabrication, Cleaning, and Certification of Stainless Steel Vacuum Chambers for Weldments for UHV by 0 . DiGennaro, LSME-50OB.

8. Mrror Brazing Technique, by D. DiGennaro, M7184.

9. Light Source Photon Beam Lines-BNL/NSLSXI Beamline Mirror System M-Zero Mirror System: General Cleaning and Brazing Procedures for Fumace-Brazed U.H.V. Parts, by D. DiGennaro, LSME-42JA.

10. ALS Beamine Design Requirements, PUB-3114. 


\section{APPENDIX C \\ Survey and Alignment Information for ALS Users}

The survey and alignment of beamlines and experimental equipment at the ALS is based on three coordinate systems. The Global Coordinate System is used to describe the location of all position-sensitive items at the ALS. In addition, the Local Coordinate System and the Beamine Coordinate System can be used to describe the location of accelerator and beamiline components.

Global Coordinate System

The three-dimensional Global Cartesian Coordinate System (also known as "ALS Coordinates") is aligned with the University of California grid system that is used for bailding construction at the University of California at Berkeley and Lawrence Berkeley National Laboratory. The Global, or ALS System has the following characteristics:

- The units of measurement are meters (m).

- The origin of the coordinate system is defined by the center point of the storage ring at nominal bearn elevation ( $1.4 \mathrm{~m}$ above the floor).

- The $Y$-axis is up, or vertical, and in the direction of gravity. The $Y$-axis increases in value in the "up" direction.

- The $X$-axis lies in a level plane, points notth, is $90^{\circ}$ to the $Y$-axis, and increases in value in a northerly direction.

- The $Z$-axis lies in a level plane, is perpendicular to the $Y$-axis and $X$-axis, and increases in value in an easterly direction.

The origin of the coordinate system at the center point of the storage ring has the following values:

$$
\begin{aligned}
& X=1500 \mathrm{~m} \\
& Y=3500 \mathrm{~m} \\
& Z=2500 \mathrm{~m}
\end{aligned}
$$

Large coordinate values were chosen to avoid negative numbers. Since the project extends no more than 500 meters in any direction, the coordinates $X=1500, Y=3500$, and $Z=\underline{2} 500$ allow an axis to be easily identified by its leading digit.

Local Coordinate 'ystem

Three-dimensional Local Cartesian Coordinate Systems can be used to define the orientation of any individual item at any given point along the particle/photon beam path. They have the following characteristics:

- The units of measurement are millimeters (mm). 
- The origin of the local cootdinate systern is defined by the center point (or another point on the individual part that is considered the survey and alignment origin) of the individual item at nominal beam elevation.

- The $V$-axis is up, or vertical, and in the direction of gravity. The V-axis increases in value in the "up" direction.

- The $W$-axis of the local coordinate system lies in a level plane, is perpendicular to the $V$-axis, points in the direction of the beam, and increases in value in the beam direction.

- The $t$-axis of the local coordinate system lies in a level plane, is perpendicular to both the $V$-axis and $W$-axis, always points in a direction away from the center of the accelerator, and increases in value in that direction.

The origin of a Local Coordinate System is defined as $V=0.0 \mathrm{~mm}, W=0.0 \mathrm{~mm}$ and $U=0.0 \mathrm{~mm}$. Negative numbers are allowed in this coordinate system.

Beamline Coordinate System
For the design and layout of beamlines, rectilinear beamline coordinates are described as $(R, S, T)$ with the following characteristics:

- Units are given in both meters (m) and inches (in.).

- The $(R, S, T)$ coordinates at the beamine source point are $(0,0,0)$. (It is essential that the beamline is first defined in Global or ALS Coordinates.)

- The $R$-axis is radially outward from the storage ring.

- The $S$-axis is vertically upward, in the direction of gravity.

- The $T$-axis is the forward direction of the photon beam.

A control network has been created to provide a reference system from which the position-sensitive items may be surveyed. The network is made up of control points, or monuments, placed in the concrete floor.

The ALS survey monuments are made up of two parts. The first part consists of a conical mount, or cup, that is set into the concrete floor, recessed from the floor surface, and provided with a protective cover when not in use. This conical mount supports a spherical adapter (sometimes called an optical tooling sphere, mounting sphere, or TaylorHobson ball). The adapter is made to a speciffc diameter and designed to bold the center of a disk type target at the exact center of the sphere. 


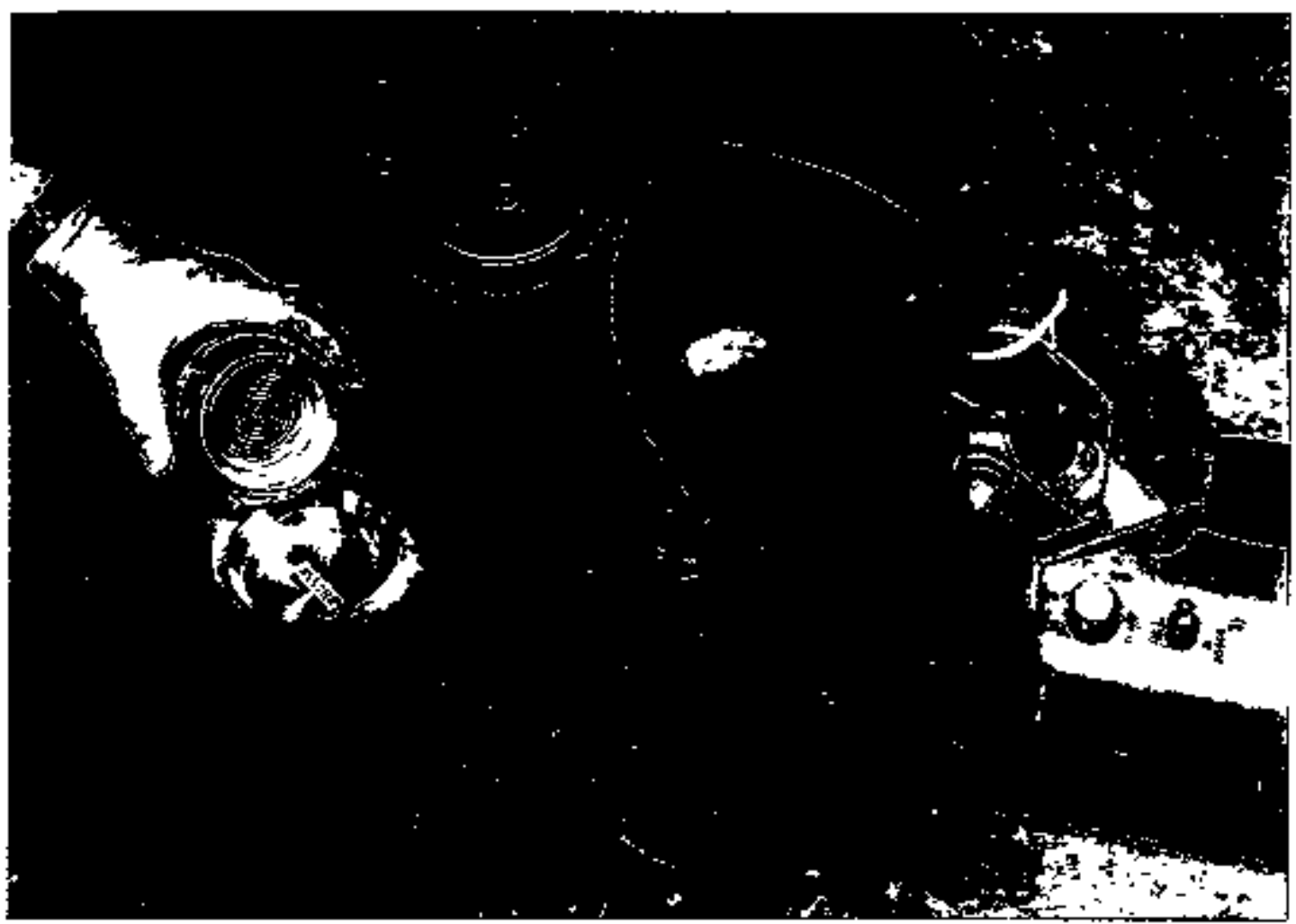

Figure 1. Remove the protective cover of the conical mount to insert the spherical adapter.

With this type of arrangement you can rotate the sphere in any direction and the center of the target remains in a fixed location. These targets are nomally used for horizontal control, but since the target holder is a sphere and extremely accurate, the ALS uses them for vertical control as well. Each monament has $X, Y, \& Z$ Global (ALS) coordinates.

The control network layout takes into consideration that survey instruments have limitations (e.g., mininum focusing distances of optical instruments, minimum ranging distances for distance-measuring instruments, minimum clearance requirements between walls and lines of sight, etc.). The monuments have been set out such that one can see (survey) at Ieast two other monuments in any direction from any single monument. 
Position-Sensitive Most beamline instrumentation and vacaam components must be aligned at instaliation. Elements To make position surveying possible, all position-sensitive branchline components must be marked with external targets or "fiducials" as reference points for measuring equipment.

In general, the components of a branchline that require precision alignment (e.g., mirrors, slits, masks, and gratings) are inside vacuum chambers and not accessible from outside for survey and alignment. Consequently, these components require "fjducialization" during assernbly, that is, the position of important internal features must be measured relative to accessible fiducial references outside the vacuum chamber. These fiducials are then used for survey and alignment at installation. For a given component, fiducialization generates a set of local Cartesian coordinates $(U, V$, and $W$ ) for each fiducial in a local coordinate system. The location of the fiducial origin (i.e., the mirror center, etc.) and a dixection must be specified in the beamline coordinate system.

Three fidecials are required for placing a component in space with 6 degrees of freedom, but four fiducials are highly desirable for redundancy, allowing a check on the survey and alignment. Fiducials are generally a precision $1 / 4 \mathrm{in}$. hole which accepts a "tooling ball" (Figure 2) for mechanical contact and measurement and an optical target (Figure 3) for direct sighting with an optical instrument. The fiducials shoutd be located with as large a separation from each other as possible and a clear vertical path above for elevation measurements.

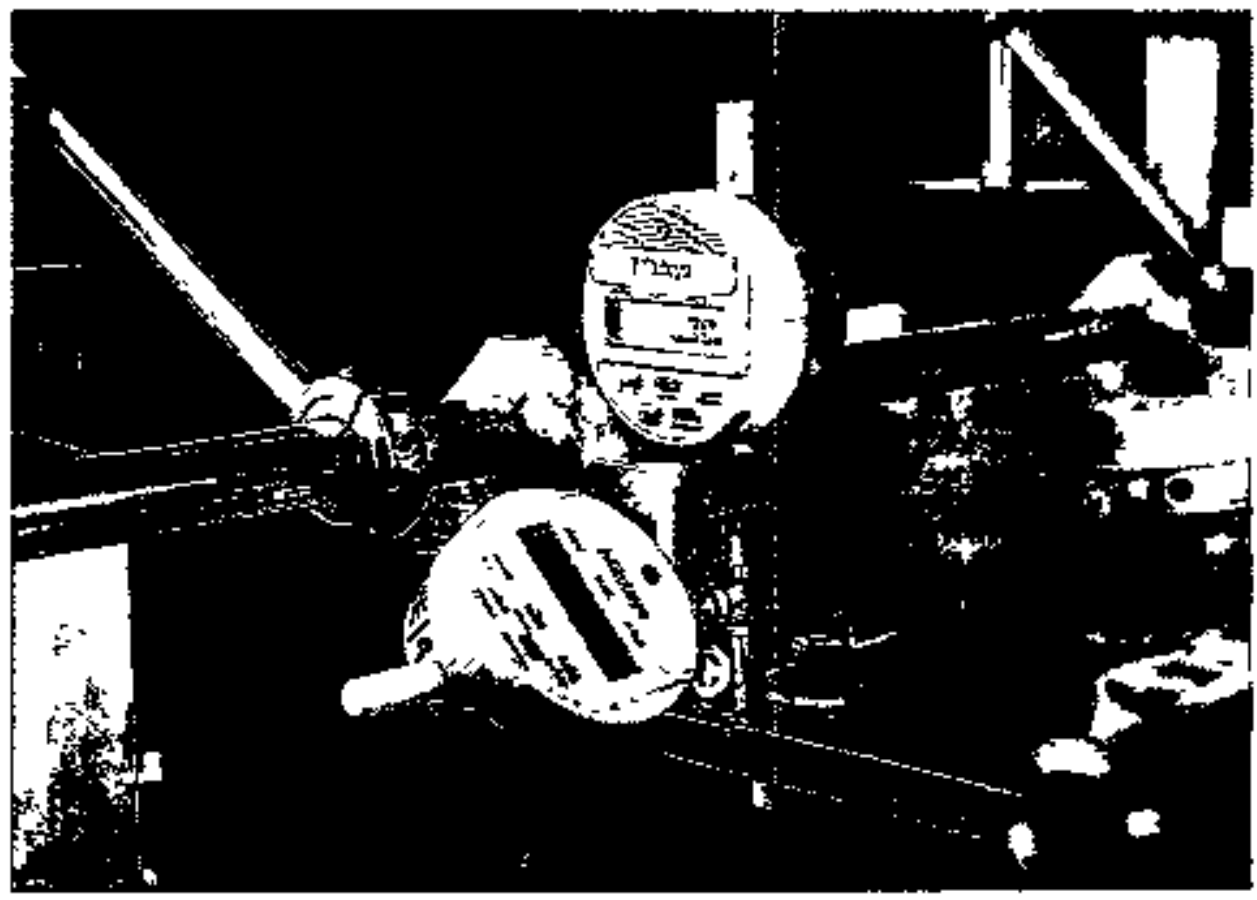

Figure 2. Fiducials must be configured to accept a tooling ball. 


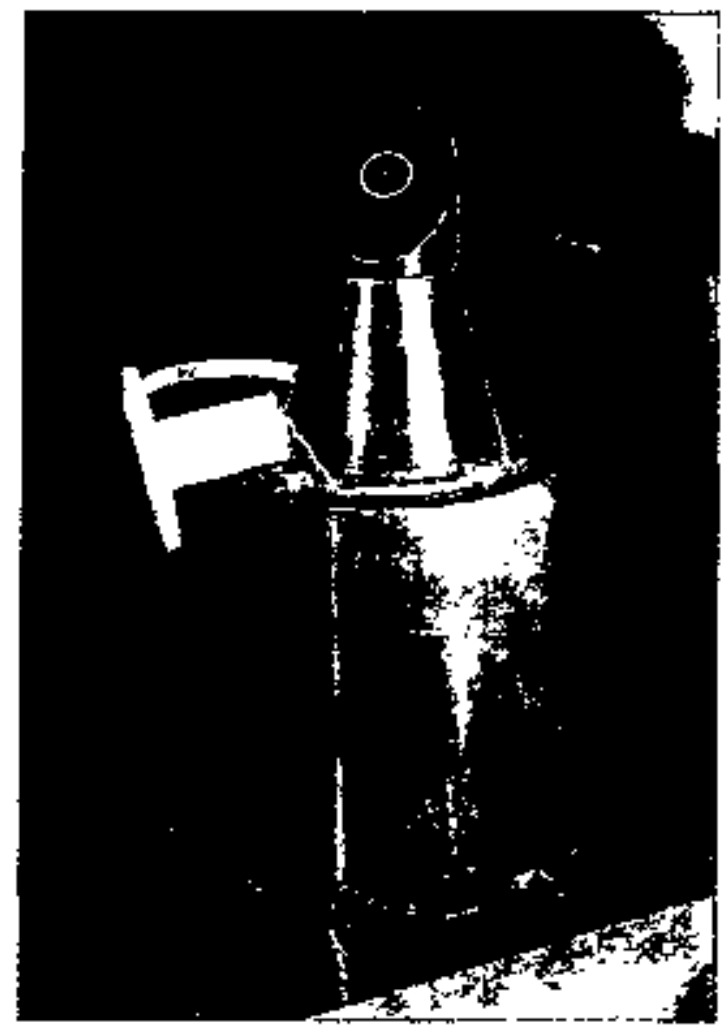

Figure 3. Fiducials must be configured to accept an optical target for direct sighting with an optical instrument.

The optical targets are constructed such that their optical center exactly coincides with the center of the tooling ball when interchanged in the same hole. This center point is the fiducial point with the local coordinates $U, V$, and $W$.

Convenient weld-on fiducial posts that accept the optical targets and the tooling balls are described in LBNL Mechanical Engineering Drawing $20 \mathrm{Q} 5363$. These fiducial posts have been used successfully throughout the ALS and are recommended.

Ted Lauritzen

November 1992

Revised by

William Thur

April 1996 
Appendix D - Beamline Readiness Review Walkthrough Procedure (BL 08-07) 

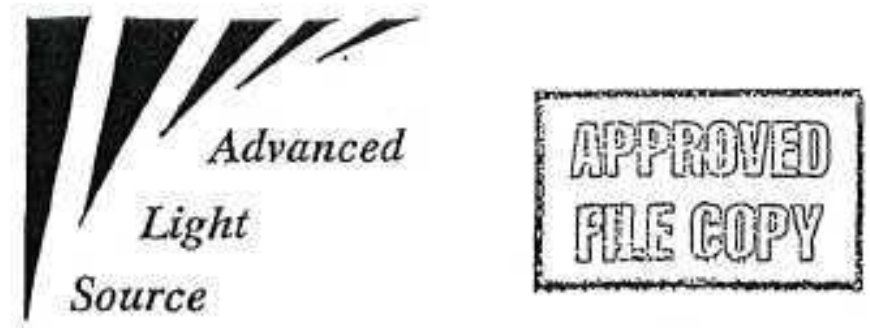

\begin{tabular}{|c|c|}
\hline PROCEDURE & $\begin{array}{l}\text { Page } \\
1 \text { of } 5\end{array}$ \\
\hline \multicolumn{2}{|l|}{ Number: BL $08-07$} \\
\hline \multicolumn{2}{|l|}{ Revision: Rev. 4} \\
\hline \multicolumn{2}{|c|}{ Issue Date: December 20,1994 } \\
\hline \multicolumn{2}{|c|}{ Review Period: 3 years } \\
\hline \multicolumn{2}{|c|}{\begin{tabular}{|c|} 
Supercedes Issues: \\
BL 08-07, Rev. 3 \\
\end{tabular}} \\
\hline
\end{tabular}

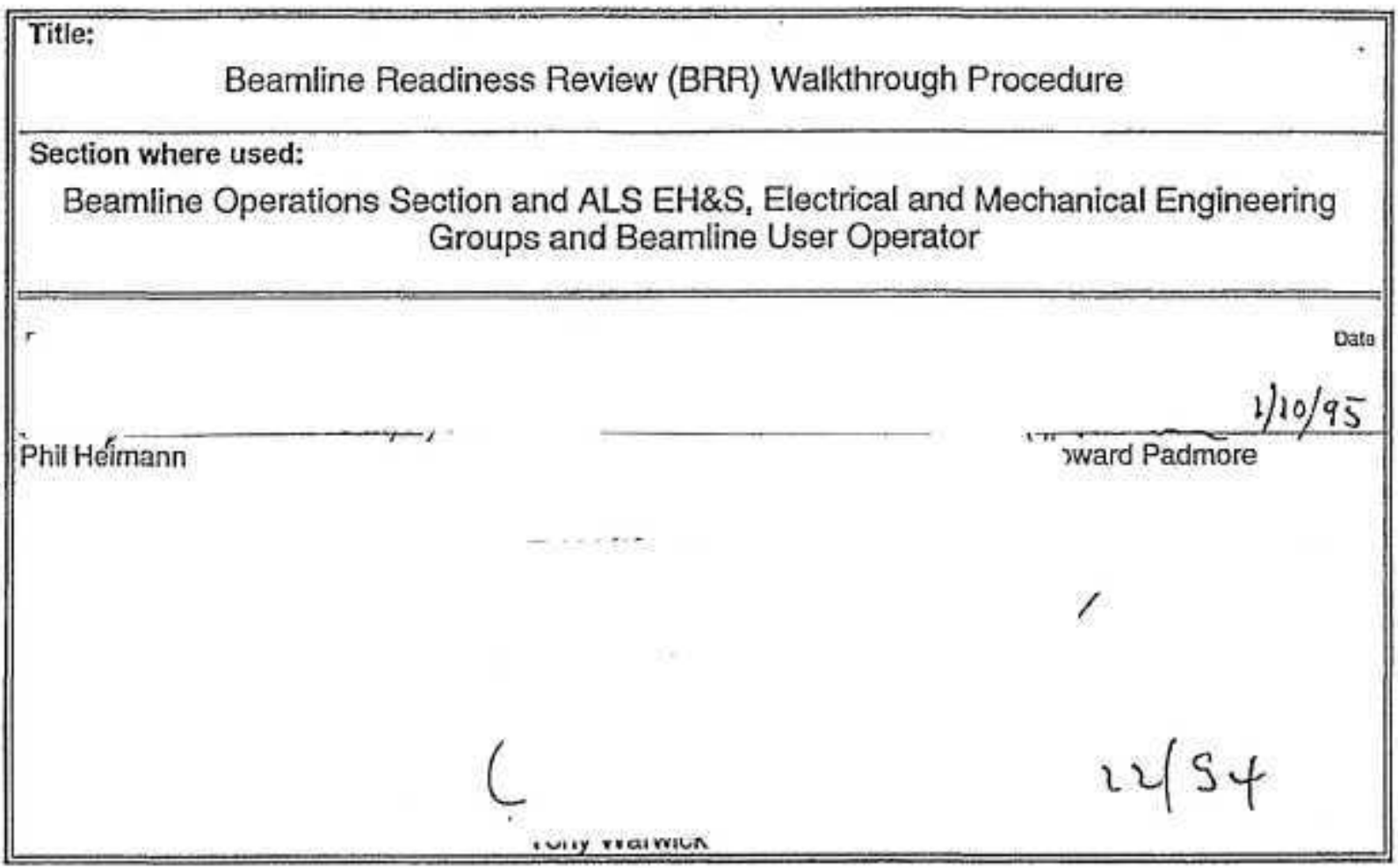

\begin{tabular}{|c|c|c|c|}
\hline & ? \\
\hline \multicolumn{3}{|c|}{$\begin{array}{l}\text { Revision Log: } \\
\text { Rev. No. IEffective Datel Pgs. Affected I }\end{array}$} & Brief Desscription of Revision \\
\hline 1 & $11 / 11 / 93$ & $1,2,5$ & $\begin{array}{l}\text { Pgs. } 1,2 \text {, and } 5, \text { Sections. } 2,0,3.0,5.0, \text { BRR checklist: references to BL } \\
08-02 \text { deleted. }\end{array}$ \\
\hline $\begin{array}{l}2 \\
3 \\
4\end{array}$ & $\begin{array}{l}4 / 29 / 94 \\
6 / 2 / 94 \\
12 / 20 / 94\end{array}$ & $\begin{array}{l}3 \text { and } 4 \\
1 \text { and } 2 \\
1,4,5\end{array}$ & $\begin{array}{l}\text { Pg. 3, Sec. 5.0, step [6] revised; Pg. 4, step [4] added. } \\
\text { Pg. 1, Signature block, reviewer added; Pg. 2, Sec. 2.0, caution added. } \\
\text { Pg. 1, Signature block, reviewer added; Pg. 4, [1], Radiation divided into } \\
\text { shielding qualification and interlock test; Pg. 5, [5], EPS divided into sub- } \\
\text { tests, [6] signature and dato added. }\end{array}$ \\
\hline
\end{tabular}

\subsection{PURPOSE}

To provide a procedure to conduct the BRR walkthrough portion of a beamline by nominated experts to check key functions of the beamline for first-time operation.

\subsection{SCOPE}

The BRR ensures that the beamline has been implemented in a manner consistent with the design approved in the Beamline Design Review. It consists of two distinct parts: a review of documentation submitted to the Beamline Review Committee (BRC) and a walkthrough of the beamline by nominated experts to check key func- . 


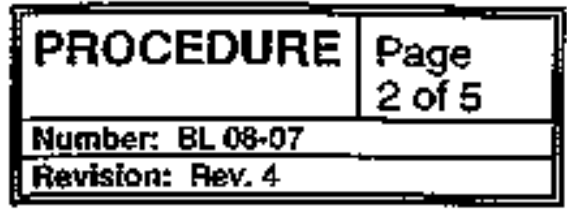

Beamline Readiness Review (BRR) Walkthrough Procedure

\section{2,0 SCOPE, Cont.}

tions of the beamine for the first time operation. This procedure provides directions for the latter.

An operations coordinator and the beamline user operator, together with representatives of the ALS EH\&S, Mechanical and Electrical Engineering groups, will follow this procedure when a new beamline is completed and needs to be approved for operation. This procedure includes procedure Bi. 08-01,Beamline Key-enable Procedure for Operations Coordinators.

CAUTION: It is inperative that the RGA scan vacuum qualification of the branchline, sfep [4] of the BRR checklist, be conducted before the EPS qualffoation, step [5] of the checklist, to prevent possible contaminafion to the front-end and storage ring vacuum.

A copy of the completed signature list, pages 4 and 5, will be filed at the beamline and the original will be filed in the Beamline Checklist Notebook located in the ALS control room (CR), Building 60 , froom 40.

\subsection{REFERENCES}

[1] DOE Order 5480.19, Conduct of Operations, Guidelines, Chapter 8

[2] DOE Order 5280.25, Safety of Accelerator Facilties, Guidance, Part II.C

(3) Procedure BL 08-01, Bearnline Key-enable Procedure for Operations Coordinators

[4] Expetimental Systems Activity Hazerd Document

[5] LBL Pub. 3114, ALS Beamilne Design Requirements

4.0 REQUIRED MATERIALS, EQUIPMENT, SUPPLIES, TOOLS, AND MANPOWER

[1] An official, checked drawing showing shlelding and exclusion zone locations, so that the positions can be checked with a tape measure, e.g. from the edge of the beam pipe - see Example 1, "BL. 7.0 Front End." The shlelding will correspond to the approved locations, presented in the Beamline Design Review.

[2] A schematic drawing naming all beamilne components, including: valves, ion gauges, pumps, windows, epertures, lead shielding, exciusion zones and optical chambers - see Example 2, "BL 7.0 Beamline Schematic."

[3] A specification of the logic of the beamline Equipment Protection System (EPS) - see Example 3, "BL 7.0 EPS Logic Dtagram." 


\begin{tabular}{|l|l|}
\hline PROCEDURE & $\begin{array}{l}\text { Page } \\
3 \text { of } 5\end{array}$ \\
\hline Number: Bl,08-07 \\
\hline Furision: Rov, 4 \\
\hline
\end{tabular}

Titite

Beamline Readiness Review (BRR) Walkthrough Procedure

4.0 REGUIRED MATERIALS, EQUIPMENT, SLIPPLES, TOOLS, ..., Cont.

[4] An appendix checklist from the Beamline Key-enable Procedure. This checklist must include a check of the bremsstrahlung shielding, the exclusion zones and an RGA scan and ion gauge reading of the beamline - see Example 4, "Checklist for BL 7.0.1."

[5] Documentation showing any changes to the beamtine made since the Beamline Design Review.

5.0 PROCEDURE

NOTE: This comprehenstve walkthrough inspection will be conducted once before the intitis beamline operation and will include intitlal execution of the Key-Enable Procedure. The Key-enable Procedure will be subsequently executed whenever the beamtine is re-enabled and put onine.

[1] The BRR walkthrough will be conducted by mennbers of the beamline operations section, the ALS EH\&S program, the ALS mechanical engineering group, the ALS lead vacuum technicians section, the ALS controls section, and the Al.S electrical engineering group.

[2] BRR Walkthrough - Checklist begins on page 4.

\subsection{APPENDIX}

Examples 1 through 4 noted in Section 4.0. 


\begin{tabular}{|l|l|}
\hline PROCEDURE & $\begin{array}{l}\text { Page } \\
4 \text { of } 5\end{array}$ \\
\hline Number: Bl 08-07 \\
\hline Revision: Prev. 4 \\
\hline
\end{tabular}

Titate

\section{Beardine Readiness Review (BRR) Walkthrough Procedure}

\section{BRf Walkthrough Checklist for Beamline}

[1] Radiation

Shielding Qualification: The position and size of the bremsstrahlung shielding and of the exciusion zones will be checked against the shielding drawing noted in Sec. 4.0 [t].

Comments:

Sgnalure

\section{Date}

Interlocks: It has been confirmed that the Radiation Safety System (RSS) has been qualified during the past 6 month period.

Sigrigaltire

Dale

[2] Electrical Qualification: The beamline has been checked for electrical safety and compliance with witing and safety standards.

Commerts:

Sintuture

Cate

[3] Mechanical Qualfication: The beamline has been checked for compliance with all relevant mechanical requitements for personnel satety and equipment protection such as seismictsiructural safety, hazards relating to mechanical motions, pressure vessel safety, visible light hazards, and covers to protect viewports and bellows from accidental damage.

Comments: 


\begin{tabular}{|l|l|}
\hline PROCEDURE & $\begin{array}{l}\text { Page } \\
5 \text { of } 5\end{array}$ \\
\hline Number Ba D8-07 \\
\hline Revision: Rev. 4 \\
\hline
\end{tabular}

Ththe

\section{Beamline Readiness Review (BRR) Walkthrough Procedure}

\section{BRR Walkthrough Checklist, Cont.}

[4] Vacuum Quatification: lon gauge readings and an RGA scan confirm that it is safe to open the beamline to storage ring vacuum.

Comments:

Signalure Date

CAUTION: It is imperative that the branchline vacutum valve, VVRt, not be opened until the vacuum qualification is completed.

[5] Equipment Protection System (EPS) Qualification: The EPS has undergone a performance test for the sector, beamline front-end, branchline front-end, and branchline.

Comments:

Sector.

$$
\text { Signature }
$$

\section{Date}

Beariline Front-end:

Branchline Front-end:

$$
\text { Signature }
$$

Date

\section{Sigrature}

Date

Branchtine:

$$
\text { Signature }
$$

Date

[6] EPBI (Errant Photon Beam Interlock] Dynamic Test: Performed for Insertion Device beamlines prior to initial operation. Test is documented in CR Operations Log.

Signature

Dave

[7]. Key-enable Procedure has been executed for the first time.

Signalure

Date

[B] A radiation survey häs beeṇ conducted.

Comments: 


\section{Appendix E - Contacts for Additional Information and Technical Questions}

Surface mail should be addressed to the recipient at:

Advanced Light Source, MS

Lawrence Berkeley National Laboratory

Berkeley, CA $\$ 4720$

ALS Administrator

Elizabeth Saucier

MS 80-101

$\$ 10-486-6166$

$510-496-4960$ (fax)

ALS User Office

For copies of all referenced documentation.

MS 80-101

$510.486-7745$

$510-486-4773$ (f2x)

Beamilne feriem Committee Cha:

For the name of current BRC Chair, and to schedule a Beamline Design Review (BDR) or Bearnline Readiness Review (BRR) contest;

AL5 Administrator

510.486 .6166

$510.486-4960$ (fax)

Beamline Stientist

The Beamline Selentist is the person in charge of an individual bearnline who has in-depth understanding of the beamiine and who is the representative and contact person for the bearriline. Contact dhe ALS User Office for the name of the person in etharge a specific bearnline.

Beamline Controls

Alan Bioce

MS 10.110

510.486 .7700

$510-486.4960(\mathrm{fax})$

Beantins Desigt

Howard Padmore

MS 2-400

510.486 .5787

510.486 .7696 (fax)
Malcolm Howells

MS 2-400

$510.486-4949$

$510.486-7696$ (fax)

Wayne MeKinney

MS 2-400

510-486-4395

$510-486-7696$ (fax)

घectrical (twiroway, cablins, etc.)

Bamy Bailey

M5 46-125

510.486 .5817

SI0-486.5775 (fax)

Electrical Engigering

Art Ritronie

MS 46.161

$510-486.4785$

$510-486-5775$ (fax)

Emirumment, Heahth, and Safeby

Georgeanima Perdue

MS 50-t01

$510.486-7407$

$510-486-5800$ (fax)

Equipment Protection System

Ken Woolfe

MS 46-125

$510-486.7739$

510-486-5775 (fax)

Laser Safety

Ken Barat

MS 90-2148

$510-486-7658$

510-486-5399 (fax)

Mecharion Ensineering

Dick DiGennaro

MS 46-161

$510-486-6466$

$510-486-4873$ (fax) 
Hechanical System Safoty

Witham Thur

MS 46-16:

$510-486-5689$

$510-486-4873$ (fax)

\section{Operalions Coordinator}

The Operations Coordinators are the firse contact for qutestions or asststance on the experimemt floor during ALs operations. They are knowledgeable abour ALS operations, fafecy regulations and training, and twamline inspection and documentetion.

Opsrations Coordinator On Ducy 510.486 .7464

\section{Procedares}

Documents

Rita Jones

MS 80-101

$510-486-7723$

510-486-5800 (fax)

Inter rock Procescturess

Ken Woolte

MS 46-125

510.486 .7739

$510-486-5775$ ( $\mathrm{max})$

Ker-Enable Procedure

Cheryi Hauck

MS 80-10I

510-486-7895

$510-486-5800$ (fax)

\section{Radiation Safety System [R5S]}

Art Ritchie

MS 46-125

$510-486-4785$

510-486-5775 (fax)

Al Lindner

MS 46-125

510-486-7757

530-486-5775 (fax)
Radiation Shielding

Hearth Physics losues

RIck Donahue

MS 7I-259

510-486-5597

510-486-7304 (fax)

Bay-Tace Drrwings and Shieldimg Construction

Diek DiGiennaro

MS 46-16|

$510-486-6466$

$510-486-4973$ (fax)

Radiation Sinney

Keith Heinzzitrian

MS 80-101

$510-486-6212$

$510-486-5800($ tax)

Solsticte

Willom Thur

MS 46- $|6|$

$510-486-5689$

$510-486-4873$ (fax)

Survey and A"Igamenk

William Thur

MS 46.161

$510-486-5689$

$510-486 \cdot 4873$ (fax)

Techuical Assistance, Work Order Requests, Hookups and Repairs

Rey Thatcher

M5 80-10I

$510-486-7412$

$510-486-5800$ (fax) 
Vacuum

Tony Catolano

MS 80-10I

510-486-6484

$510-486-4990$ (fax)

Dick DiGennaro

MS 46-16I

510-486-6466

510-486-4873) (fax)

Ray Thatcher

MS 80-10I

$5 \mid 0-486-7412$

510-486-5800 (fax)

John Thomson

MS 80-101

510-4B6-7975

510-486-4590 (fax)

\section{Utiteries}

Barry Bailey

MS 46-125

510-486-5817

510-486-5775 (fax)

Ken Rex

MS 46.161

510.486 .4826

510.486 .4873 (fax)

Operations Schedulinge Heeting

ALS Operazions Scheduling Meeting held Fridays, 3:30 p.m., Building 6 conference room

Chair: Bob Miller

MS $60-140 \mathrm{D}$

$510-486-4738$

$510-486-5800$ (fax)
Additonal Sources of Infonmatton Available Fromis ALS User Office MS 80-101

510-486-7745

$510-486-4773$ (fax)

ALS Beamline Rack Nombering Scheme (LSEE-107A)

ALS Experiment form

ALS Sofety Hondbook (PUB-745)

ALS Synctirotron Rodiation Shielding (LBL-37801)

Bromsstrahiung Colimorion and Shielding for ALS US and UB Beamilines (LSBL-058A)

Gas Bremsstrablung Estimates for ALS Hutch Backstops (LSBL-162)

LBNL Chemical Hygiene and Safety Plan (PUB-534l)

LBNL Health ond Sofety Monual (PUB-3000); also available on the World Wide Wes ar: hatp://ehssun.bl-gor/ehsdiv/pub3000I

LBNL Mechonital Enguineering Drowing 20 Q 5363

Rodicuton Sofety Shutters, Callimotion and Shtedding for ALS Beomitines (LSBL-073)

Sample copy of the Beamline Design Review document padage 
Appendix F - Checklist and Timeline for Building a Beamline 


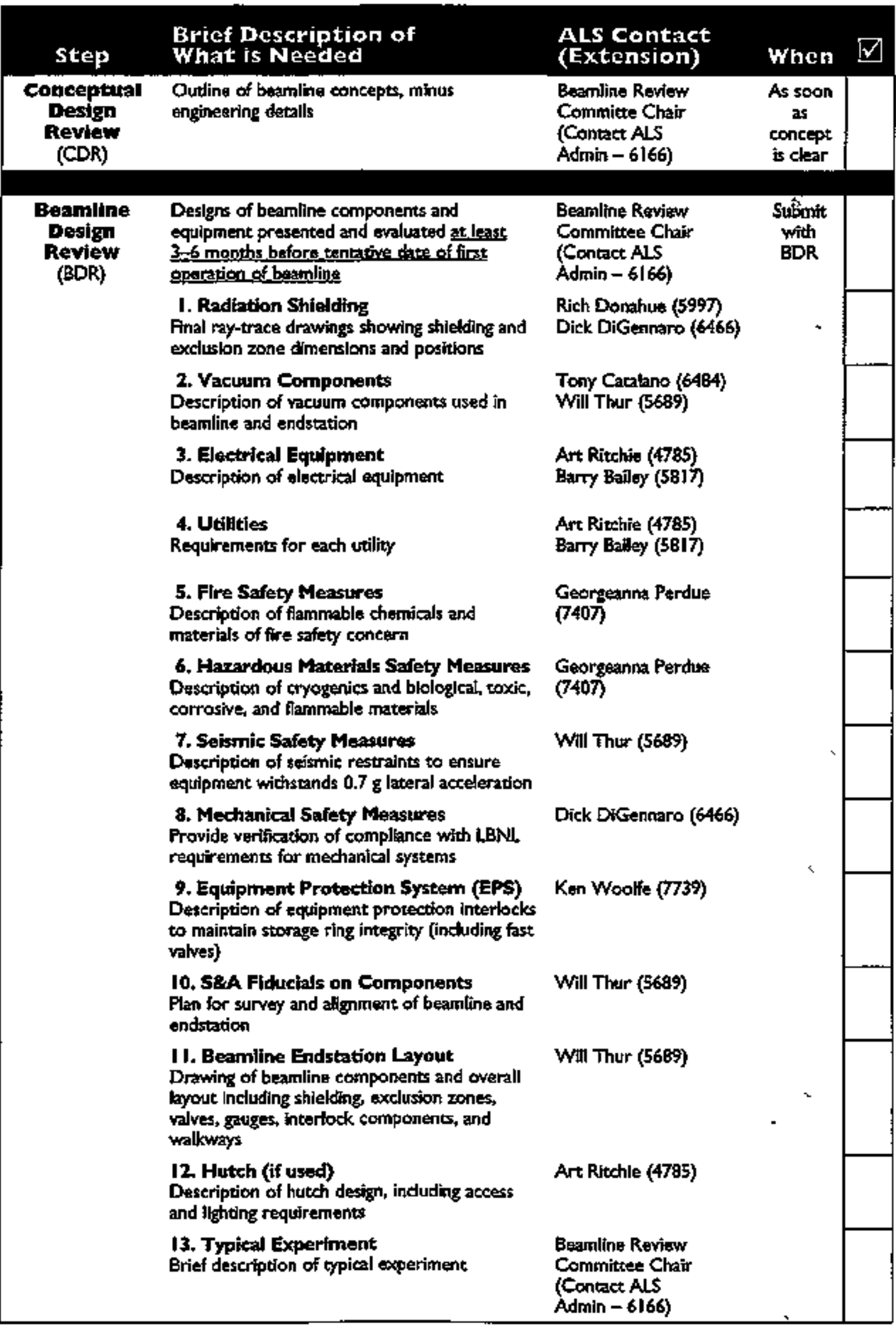




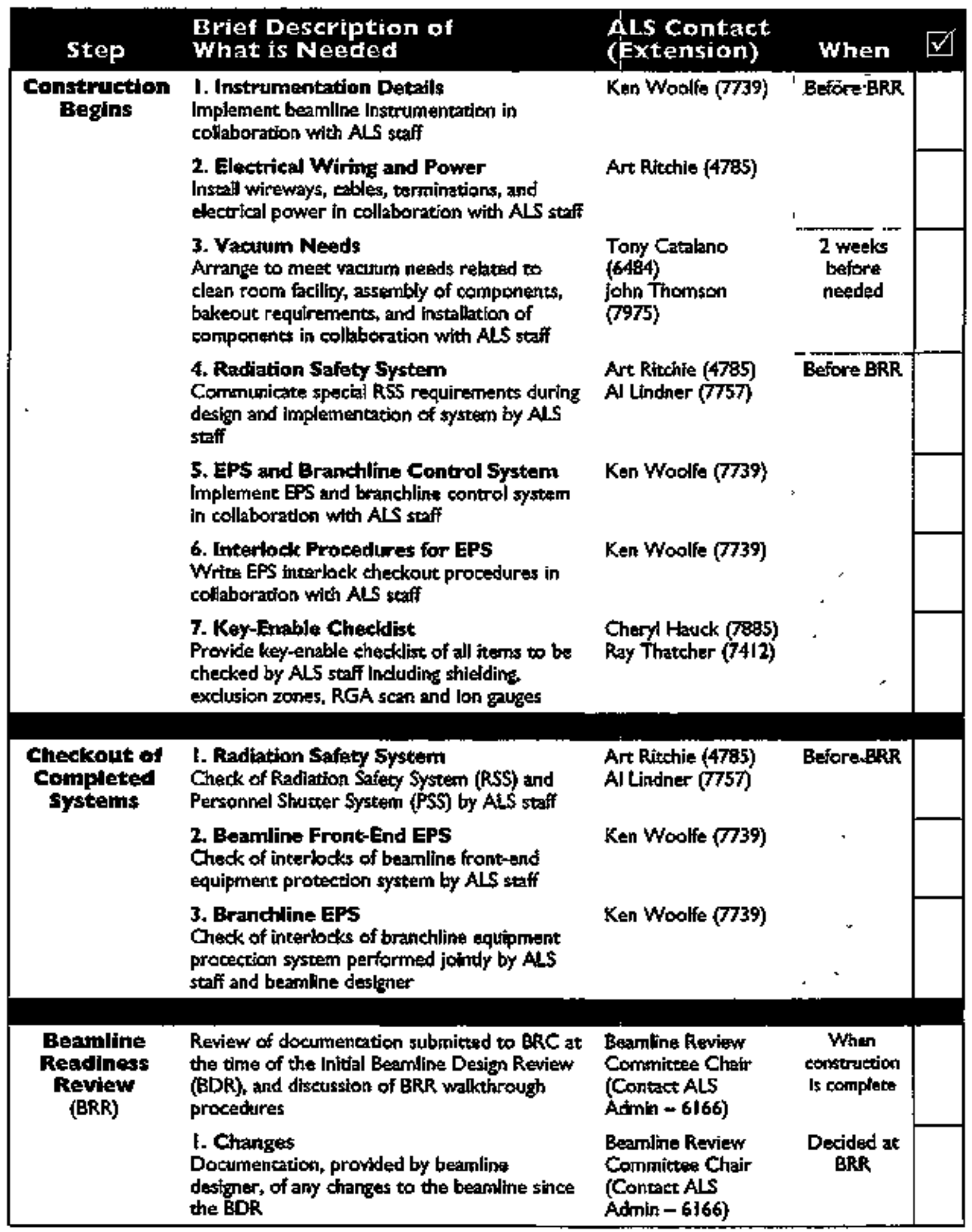




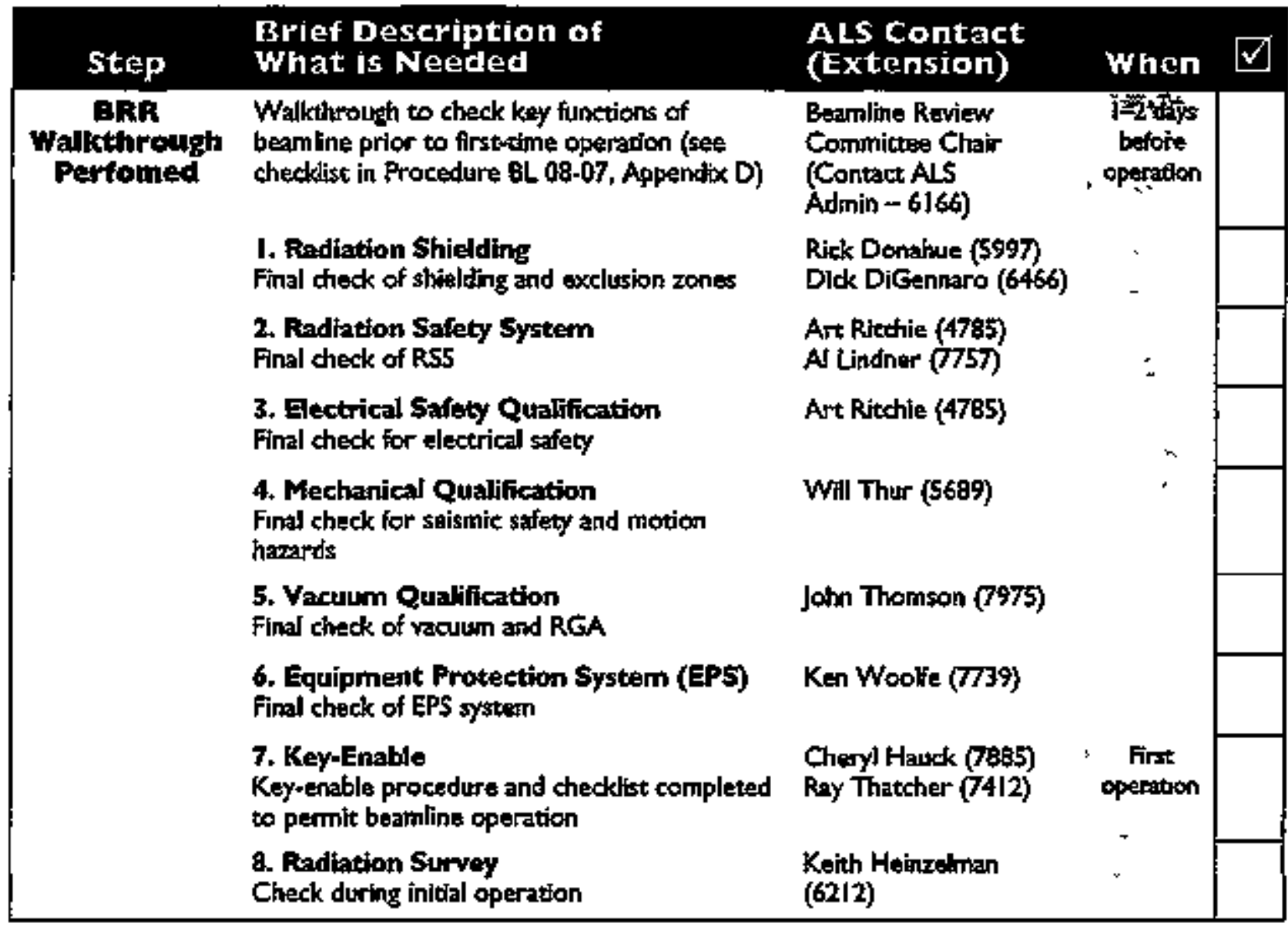


Appendix G - ALS User Advisories 
This Appendix includes ALS User Advisories related to beamline design.

This list is current as of June 1996. Please contact the ALS User Office for the most current list of Advisories.
ALS User Office
Advanced Light Source, MS 80-101
Lawrence Berkeley National Laboratory
Berkeley, CA 94720
510-486-7754
$510-486-4773[\mathrm{fax}]$

Copjes of all Advisories are also located on the World Wide Web at the following address:

htap:/beanie.lbl.gov:8001/als/user-advis/user_adivis_index.html

\begin{tabular}{|c|c|c|}
\hline Catejary & Aulvisory \# & Title \\
\hline \multirow[t]{5}{*}{ 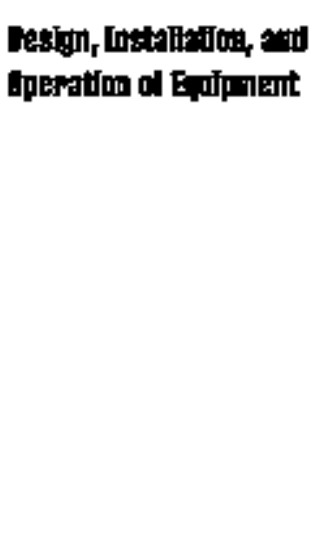 } & 1 & $\begin{array}{l}\text { Affixting Beamline and Endstation Components to the ALS Foor: } \\
\text { Location of Grade Beams and Conduits }\end{array}$ \\
\hline & 2 & Electrical Cable Wire and Routing Requirements \\
\hline & 4 & $\begin{array}{l}\text { Guidelines for Meeting Seisnic Requirements for User Equipment } \\
\text { at the ALS }\end{array}$ \\
\hline & 9 & $\begin{array}{l}\text { Vacuum Policy for User Endstations for Protection of Bearnitine } \\
\text { Components and Storage Ring Vacuum }\end{array}$ \\
\hline & 13 & Inspection of Beamine Work and Repairs \\
\hline \multirow[t]{2}{*}{ Bectritioal 8aristy } & 3 & Avoiding Overloads on AC Circuits \\
\hline & 5 & Beamline Electrical Safety Guidelines \\
\hline Lexter saipty & 6 & Laser Safety Policles for Class 3b and Class 4 Lasers \\
\hline
\end{tabular}




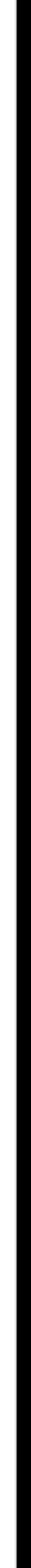

